\title{
EXAMINING AND GRADING GRAINS
}
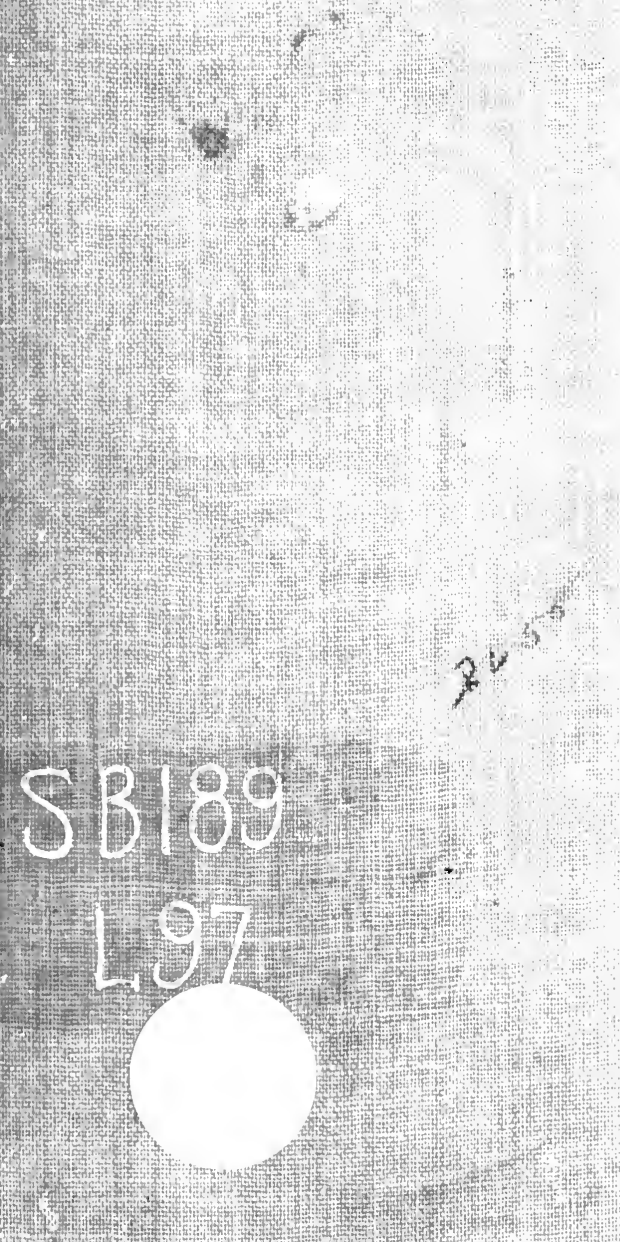


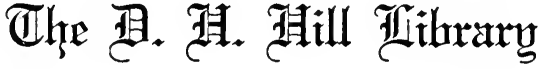

Zurth Uaralina State Uallege

$$
\begin{gathered}
5 B 189 \\
297
\end{gathered}
$$


d) Ales usu

SEP Z 459667

Apr 13 3ests

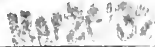

a. 23

GFats:

$22 M y^{\prime} 44 H$

1OAUE' 4 A $^{4}$

1140 S $^{58}$

2a 4ug' 60:

Erats?

10Aug' $\Delta^{\prime}$

22!

$13 / 3$

$2^{50}$ 


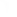




\title{
EXAMINING AND GRADING GRAINS
}

\author{
BY \\ T. LYTTLETON LYON, PII.I). \\ Professon of AgRonony, Uxivelist \\ AND \\ E. G. MONTGOMERY, B.SC.

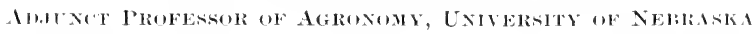

GINN \& COMPANY

BUSTON - NEW YORK $\cdot$ CHICAGU $\cdot$ LUNDON 
COPYRIGHT, 1907, $\mathrm{H}$

T. LYTtLeton Lyon AND E. G. MONTGONERY

ALL Rights RESERVED

77.3

The Atben xum Press

GINN\& COMPANY. PRO. PRIETORS - BOSTON - U.S.A. 


\section{PREF A CE}

Two years ago we published for the convenience of our students the exercises used in our field-crop laboratory. These exercises seemed to meet the needs of other teachers, and during the past year a number of the agricultural colleges and a few normal sehools have used the publication.

No laboratory manual in field crops harring been published previous to this time, and comparatively little having been done towards developing a systematic laboratory course in this subject, it was thought that a course might be worked out that would be of at least temporary usefuhness, and would make for uniformity in laboratery instruction, by getting the opinions and, as far as practicalble, the methods of those giving such instruction, and incorporating these in a new edition of "Examining and Grading Grains." This has been done, and we wish to express our thanks for counsel and material contributed by Professor Alfred Atkinson, l'rofessor C. P. Bull, Professor F. C. Burtis, Professor (i. A. Crosthwait, P'rofessor .James A. Foord, Professor A. N. Hume, Professor Thomas F. Hunt, Professor F. S. Johnston, Professor A. C. MeCall, Professor M. F. Miller, Professor W. H. Olin, Professor ( ieorge Severance, Professor V. M. Shoesmith, l'rofessor A. L. Stone, Professor A. M. Ten Eyck, Professor A. T. Wiancko.

The exercises are planned to cover about one year's laboratory work of four hours per week. The work is intended $r^{2}-$ iii 
for agricultural colleges and well-equipped normal or high schools. Most of the exercises are easily modified to suit local conditions or the equipment of the school.

It has not seemed best to discuss in the text methods of teaching the sul,ject. We have, instead, prepared a pamphlet giving suggestions for collecting material and conducting the work. This can be secured from the publishers.

THE ACTHORS

Lixcola, Nemiask 


\section{(O) N'TEN'TS}

WHEAT

PIGE

('lassification of speches ani) Varieties. . . . . . . 1

Laboratory Stem of Characters . . . . . . . . . 3

Terns for describiNg Wheat . . . . . . . . . . . 4

Outline for Describing Wheat . . . . . . . . . . 8

Examining tile Quality of Wheat . . . . . . . . !

Report Cari, (Wheat). . . . . . . . . . . . . . !

Notes on the Quality of Wheat . . . . . . . . . 10

JUdGiNG WheAT . . . . . . . . . . . . . 14

Score Card for Wheat . . . . . . . . . . . . . 14

Explanition of Scole Card . . . . . . . . . . . 14

Determixing the Gliten Contest of Wheat . . . . . 17

Conmerchal Grahisg of Whent . . . . . . . . . 17

Wheat Inspection Riles. . . . . . . . . . . 18

Testive Wheat for Purity. . . . . . . . . . . . 20

Testive Whelt fole Vinhliti. . . . . . . . . . . 20

Sten of Variation in Wheat Plants. . . . . . 21

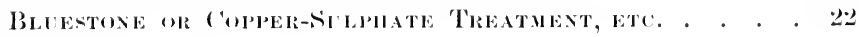

\section{CORN}

Classification of Spectes . . . . . . . . . . . 25

Varieties of Cors . . . . . . . . . . . . . . . . 26

Laboratory Stum of sipeches and of Characters . . 26

Exanination of Speches . . . . . . . . . . . . . 26

Terms for describing Cork. . . . . . . . . . . . 27

Outhine for describing Cors . . . . . . . . . . . . 32

Comparative Study of Characters. . . . . . . . . 32

Judging Corn . . . . . . . . . . . . . . . . . 33

Points to be Observel, . . . . . . . . . . . . . . . 84

Score Card for Corx, No. 1 . . . . . . . . . . . . 42

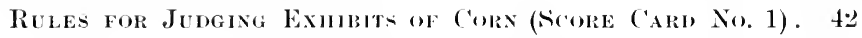

Score Carl for Corx, No. 2 . . . . . . . . . . . 45

Rules for Judgini Exhibits of Corx (Score Cari No. 2), 45)

Testing Cors for Viability . . . . . . . . . . . 47 
PAGE

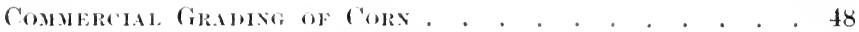

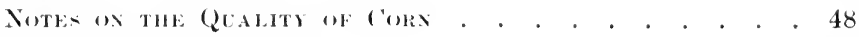

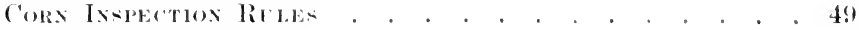

\section{( $\mathrm{NTS}$}

Claseifleathos of Species . . . . . . . . . . . 51

LABORATORY STTIM OF CHARACTERS . . . . . . . . . 5.9

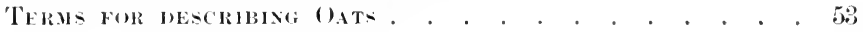

()TLINE FOR DESCRHBNG (OATS . . . . . . . . . . . 56

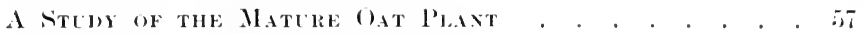

Exinisise the Qlality of (late. . . . . . . . 58

RePOrt Carh (OATS) . . . . . . . . . . . . . . 5!)

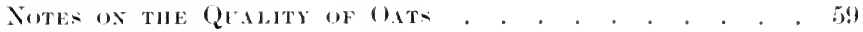

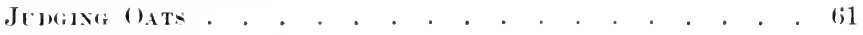

SCORE CARH FOR OATS . . . . . . . . . . . . . . . (i1

Explanatox of Ścole ( 'ard) . . . . . . . . . (i2

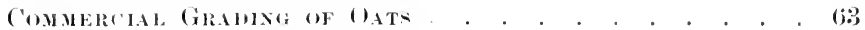

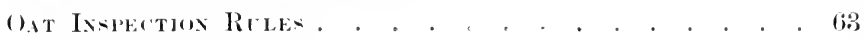

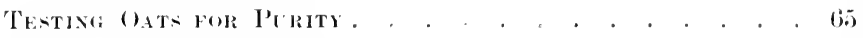

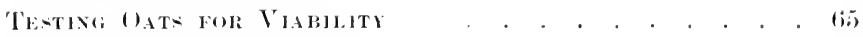

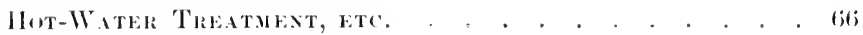

Formalis 'Theatukit, etc. . . . . . . . . . . . . fifi

\section{BARLEY}

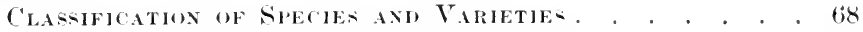

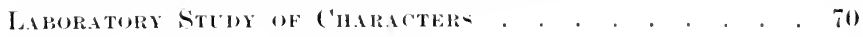

TERMS FOR DEACRIBISG BARLEYS . . . . . . . . . 70

()TLANE FOR DESCRIBING BARLEYS . . . . . . . . . T4

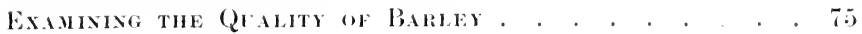

Report Carh (BARLEY) . . . . . . . . . . . . 75

Notes ox the Quality of Baller . . . . . . . . . T6

JPMING BARLEY . . . . . . . . . . . . . . . T8

Sicore Calie for Barley . . . . . . . . . . . . T8

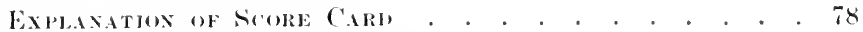

Condercial Graming of Barley . . . . . . . . . . 80

Barley Instectoon Rithe . . . . . . . . . . . 81

Testina Barley fol Prrity and Vhableity . . . . . 82

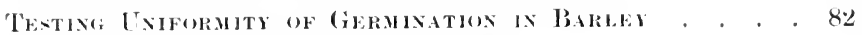

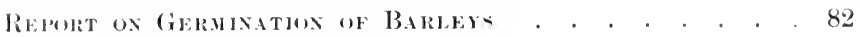




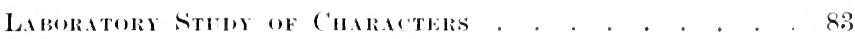

OtThine fol meacribing Grasies. . . . . . . . . . . 83

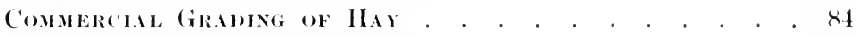

Har axp straw Ixapectox licles . . . . . . . . . 84

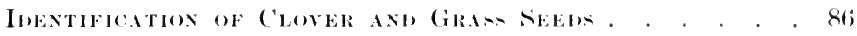

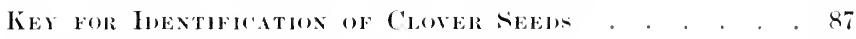

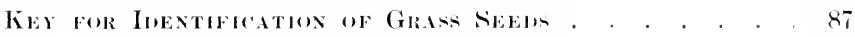

Key for Identification of Millet sliems . . . . . . . 90

\section{SEEI TESTING}

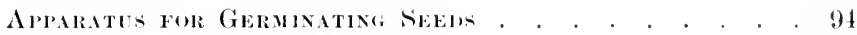

Honemade Germinators . . . . . . . . . . . . . . 9 94

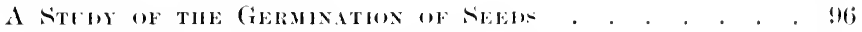

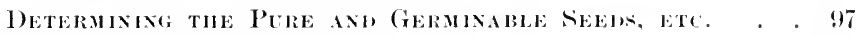

Siggentel form for Report . . . . . . . . . . . 98

Deternisation of Weight per Benhel . . . . . . . 98

Practele Work with Tester . . . . . . . . . . . 99

Test for MolstiRe in Groin . . . . . . . . . . . 9.9

Legal Weights of Selens per Bushel. . . . . . . 100 


\section{EXAMINING AND GRADING GRAINS}

\section{SECTION I - IVHEAT}

\section{CLASSIFICATION OF SPECIES AND VARIETIES}

Wheat belongs to the family of plants known as the Grominece, which includes all of our cereal crops and meatlow grasses. It is classified into several species and varieties, founded on distinct differences.

All of the Gromined are readily distinguished by having only one seed leaf and ane technically known as monocotylectons.

Wheats seem to be most properly dissitied into species and races as follows:

Triticum monococum (1-grained wheat): spikes compact, spikelets 3-flowered but 1-grained, bearded ; very old, belongs to Stone Age; grown in spain, Germany, Switzerland; not much of a bread wheat.

Triticum P'olonicum (Polish wheat): large, open heads, spikelets 2-to-3-seeded, hearded; seeds long, bright, and glossy ; cultivated in parts of eastern Europe and northern Africa.

Triticum satirum, divided into races as follows:

Tr. sat. vulyare (common wheat): 4-flowered spikelets, 3-grained, both hearded and heardless; our common

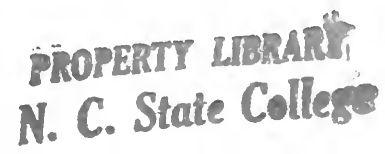


bread wheats, many varieties, almost exclusively grown in this country.

Tr. sut. compuctum (" Heilgehog wheat," "Iwarf wheat"): spikes short, dense, distinctly 4-sided, both bearded and beardless; grown in Switzerland and neighboring region, also in Turkestan and chile.

Tr. sut. turgidum ("English wheat," "Egyptian wheat"): spikes large, dense, t-sided, "2-to-3-seeded, bearded; largely grown in Mediterranean comntries, also in Egypt, England, and Germany.

Tr. sut. durum (true bearded, or hard wheats): spikelets :-to-4-seeded, long, stiff awns; seeds large, bright, and glossy. This race comprises the so-called "macaroni" wheats, which are at present being extensively tested in the semi-arid portions of the country. They are widely grown in eastern Europe and northern Africa. Tr. sut. Speltu (spelt): spikes long and very loose, darkish colored when ripe, spikelets 3 -seeded at base, 2 at top of spike; chaff adheres to grain; little grown in this country; at home in the mountain regions of Europe and Asia.

Tr. sut. dicorfum (Emmer): spikelets 2-seeded, rather compactly arranged in 2 rows, generally dark colored, grain very hard, inclosed in chaff; little grown in this country; more common in central Europe.

The varieties of Tritioum durum, commonly known as "macaroni wheats" hecause of the excellent quality for the manufacture of macaroni and similar pastes, are considered strongly drought-resistant and give promise of becoming valuable wheats for the semi-arid regions of this country. 
Emmer ( $T$. dicoceme, commonly confused with slelt, also gives promise of a wide usefulness. Of these wheats we are principally concerned with the varieties of Triticum sativum velyaie.

\section{LABORATORY STUIY OF CIIARACTERS}

Let the teacher provide each student with specimens of the
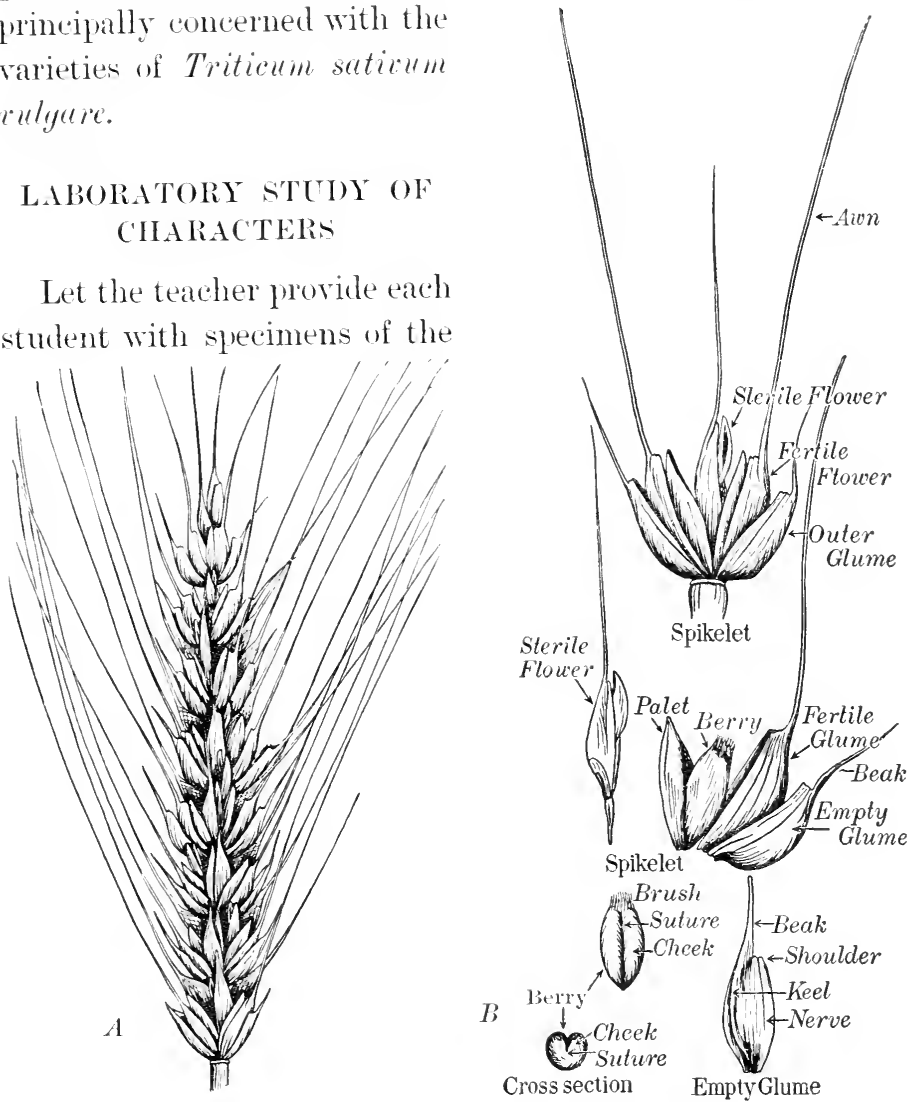

FIti. 1. On the left is shown a whole wheat spike. ()n the right the structure of a spikelet is illustrated and the varions parts named

types included in the above classification, and try to identify the specimens by use of the descriptions given. After this 
the stulent should proceel to study these wheats, and as many specimens of native wheats as he can obtain, according to the following method. ${ }^{1}$

Draxings. Make a lrawing from a spike of each of the trpes as follows:

First, the spike as a whole; then, removing a spikelet, draw this entire, showing the imbricated view. Then dissect the spikelet, drawing each part out separately, being careful to arrange the parts in their proper relative position.

The method of cross fertilizing wheats may now be easily explained.

The rheat spite and descriptive terms. The following is a list of descriptive terms which apply to the wheat spike. The student is supplied with two or three spikes of the wheat to be described, and proceeds to fill out the blank used in describing wheats, using the list of descriptive terms as a reference.

\section{Spike}

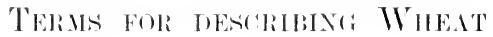

\footnotetext{
(Beardless (Fig. … Ri).

1. $\{$ Partly hearited (Fig..... (').

Bearled (Fig. - 1 ).
}

2. Length. inches.

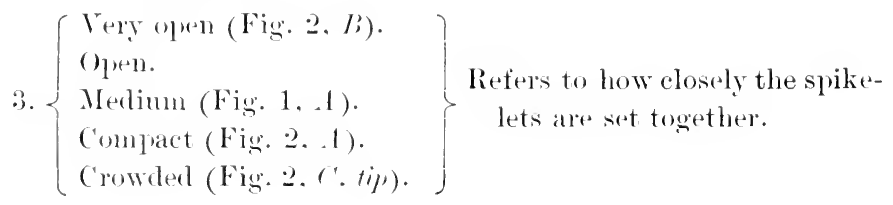

1 All specimens of grain in head will be in better condition for study if placed in a moist chamber, or between pieces of moist paper for a few hours, in order to toughen the parts. 
Shrome

S Tapering toward apex. IJeads which taper grathally from the middle toward the tip.

Tapering both ways. Ileark which are spindle shapeel or largest in midllle.

1. Iniform (Fig. …1), Heads same diameter thromghont.

Clubberl (Fig. 2, (').

lleads larger at tip'

than below.

Sinuare. Refers to cross section.

Flattened with spikelets (Fig. 1, 1).

Diameter of hear through spike-

2. $\{$ lets least.

Flattened across spikelets (Fig. $2,1)$.

Diameter through spikelets greatest.

Sterile spikelets, 1 , $2,: 3,4$.

3. $\{$ Sterile spikelets at tip and base of spike.

Colo)
Whitish.
Yellow.
Yellowish brown.
1. $\left\{\begin{array}{l}\text { liosy. } \\ \text { Red. }\end{array}\right.$
Bluish.
Brown.
Black.
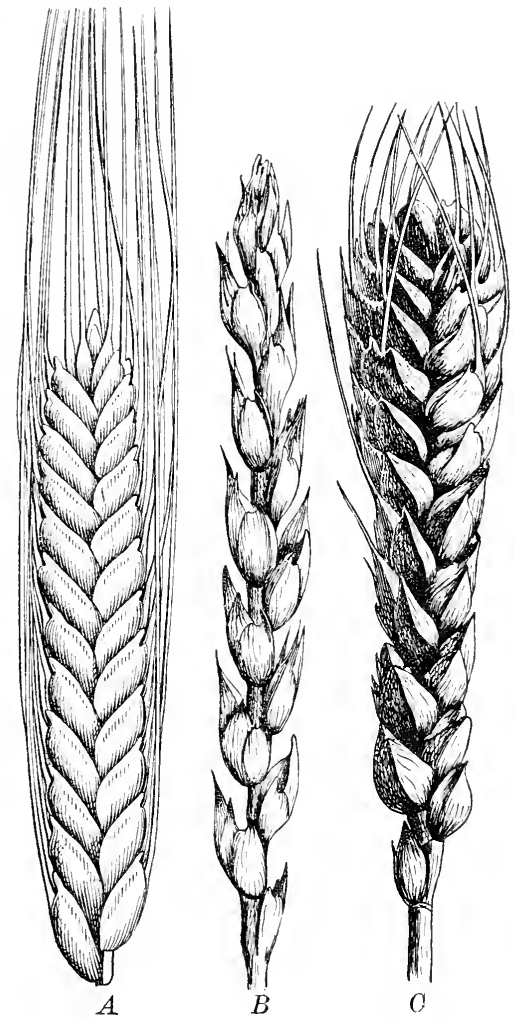

Fir. 2. Three types of wheat heads: $A$, macaroni wheat ; $B$, a common form of awnless winter wheat; $C$, club wheat 


\section{Awns}

Lomg, 4 in. tr more in length.

1. $\{$ Morlinn, 2 in. to $t$ in. in length.

thort. 2) in. or less in length.

Parallel (Fig. 2, 1$)$.

2. $\{$ rireating.

II as reference to the relative sprealing widely (Fig. 1, 1). $\}$ position of awns and spike.

I)reidnous. Awns falling as soom as grain is mature.

:2. $\{$ Partly decidnous.

Persistent. Awns not falling off naturally.

\section{Spikelet}
(Fineading widely (Fig.: :, $l ;)$.
1. $\{$ sipeacling.
(Narrow (Fig. 3, 1).
Refers to the relative wirth of the spikelet.

2. Numluer of grains, 1, 2, :?, 1, ) $, i, 7$.

Unter glume

1. $\left\{\begin{array}{l}\text { Ilairy (Fig. } 1, B \text { and }{ }^{\prime} \text { ). } \\ \text { Partly hairy. } \\ \text { smooth (Fig. } 4,1 \text { and } D \text { ). }\end{array}\right.$

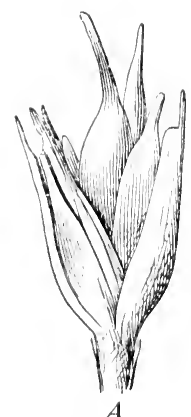

A

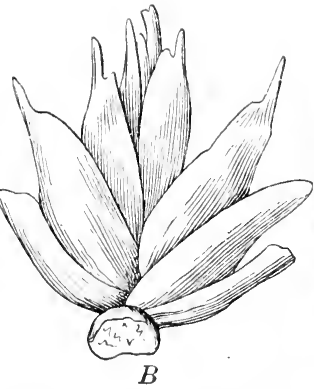

Fu. 3. Two trues of wheat spikelets

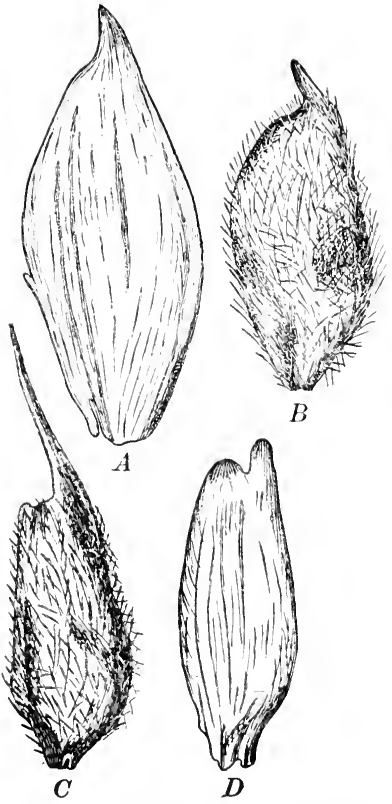

Fir. 4. Types of outer glumes 


\section{Grain}

$$
\text { 1. }\left\{\begin{array}{l}
\text { Very hard. } \\
\text { IIard. } \\
\text { Mediun. } \\
\begin{array}{l}
\text { Noft. } \\
\text { Very soft. }
\end{array}
\end{array}\right\} \begin{gathered}
\text { This point is determined by liting or cutting } \\
\text { standard samples. }
\end{gathered}
$$

rize

Weight of 100 average seeds in grams.

\section{Color}

$$
\left\{\begin{array}{l}
\text { Whitish. } \\
\text { Yellowish. } \\
\text { Clear amber. } \\
\text { Inll anber. } \\
\text { Clear red. } \\
\text { Inll red. }
\end{array}\right.
$$

Cross section

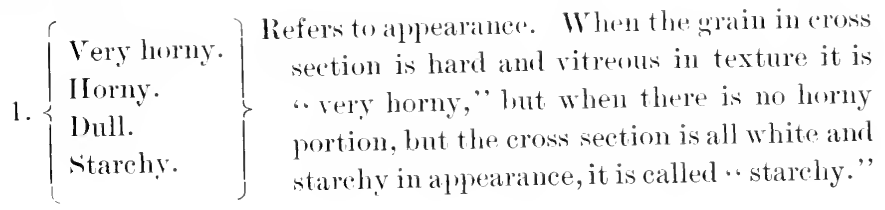

\section{General characters}

1. $\left\{\begin{array}{l}\text { II ardy. } \\ \text { Delicate. }\end{array}\right.$
$\therefore$.. $\left\{\begin{array}{l}\text { Early. } \\ \text { Medium. } \\ \text { Late. }\end{array}\right.$

:). Days maturing.

4. $\left\{\begin{array}{l}\text { Autumn-plantel. } \\ \text { spring-planterl. }\end{array}\right\}$
These points an only be determined by referring to field notes on the variety. 
OCTLINE FOR IESCRAST: WHEAT

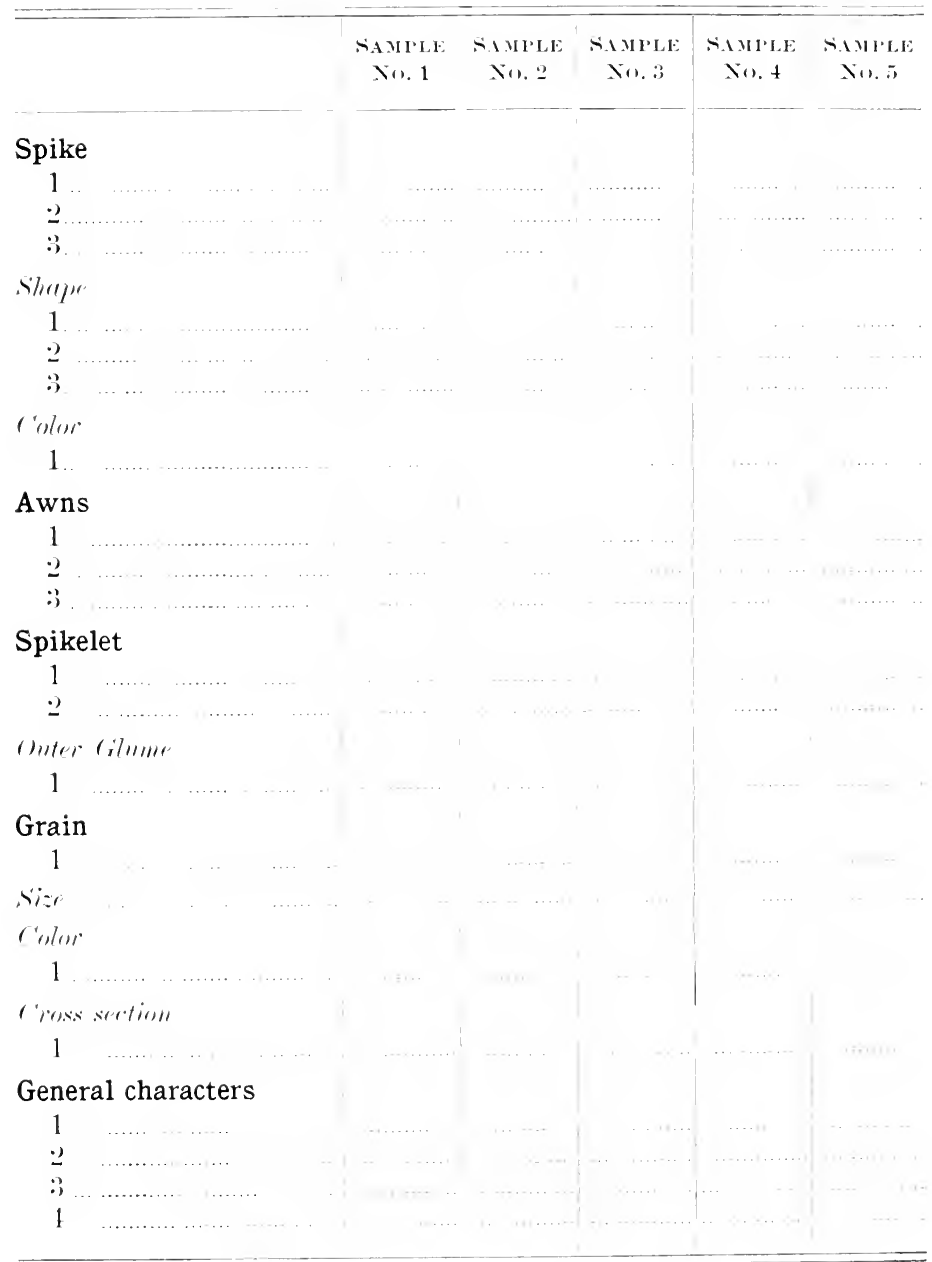

Sturlent's Nante

Date. 


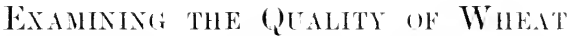

Each sturlent should be povided with about ten samples of wheats. These should represent as great a variety of qualities as possible.

The first five samples might he arrmgerl according to the degree of hardness, and the following arrangement is suggesterl: No. 1, Macaroni Wheat; No. 2, Hard Winter : No. 3, Northwestern Sining; No. 4, Red Winter: No. 5, White Winter. The rest of the samples may all be of one type, as Hard Winter, or Red Winter. hut should represent sereral different graules.

\section{liepoit rearl}

WHEST

No.

Variety

IV eight me hishel

$11 \ldots$

Whitish

Yellowish.

$1+2 \cdot \cdot r e n t$

Color $\left\{\begin{array}{l}\text { clear amber } \\ \text { bull amber }\end{array}\right.$

lere cent

Clear red

I)ull red

pere cent

Ensound grain

per cent

Foreign matter

ler cent

Hardness
amd
texture $\left\{\begin{array}{c}\text { Hard and } \\ \text { vitreous........ } \\ \text { Intermediate } \\ \text { Soft and starelyy }\end{array}\right.$

per cent

ler cent

per cent

Weight of 100 grains

....grams

size ( Large

per cent

of MIetlium

per cent

grain Small.

per cent

Viability

jer cent

[Fol:M No. I] 
Let the student now carefully compare the first five samples as to hardness, texture, color, size of berries, ete. This is most easily accomplished by filling out a blank card for each sample, similar to Form No. 1 on page 9. This gives a qualitative analysis of each sample and necessitates a critical sturly. He should understand clearly the correlations between hardness, texture, and color; how these are affected by climate, soil, and moisture; in what way they affect the bread-making qualities of the wheat; and in what regions the different types are principally grown. In the judging and grading work which follows, these five samples should be used as standards in hardness, texture, and color.

The following notes of general information should be carefully read by the student.

\section{Notes on the Quality of Wheat}

Hardnes. The hardness of wheat varies greatly in different sections of the country. This is due to the definite effect of environment. Wheats grown in a region of abundant rainfall and under humid conditions, or under irrigation, are usually softer and lighter colored and lower in protein content than wheats grown under dryer conditions.

Winter wheats grown in most of the states east of the Mississiplu River are of the softer type and are known as "red" winter wheats, while those grown in the belt of country bordering on the semi-arid and rumning through Nebraska, Kansas, and Oklahoma, are generally of the hard, dark red type, and are known as "hard" winter wheats.

The hard winter wheats are mostly of the Turkish Red variety. The characteristics, however, which mark it as a 


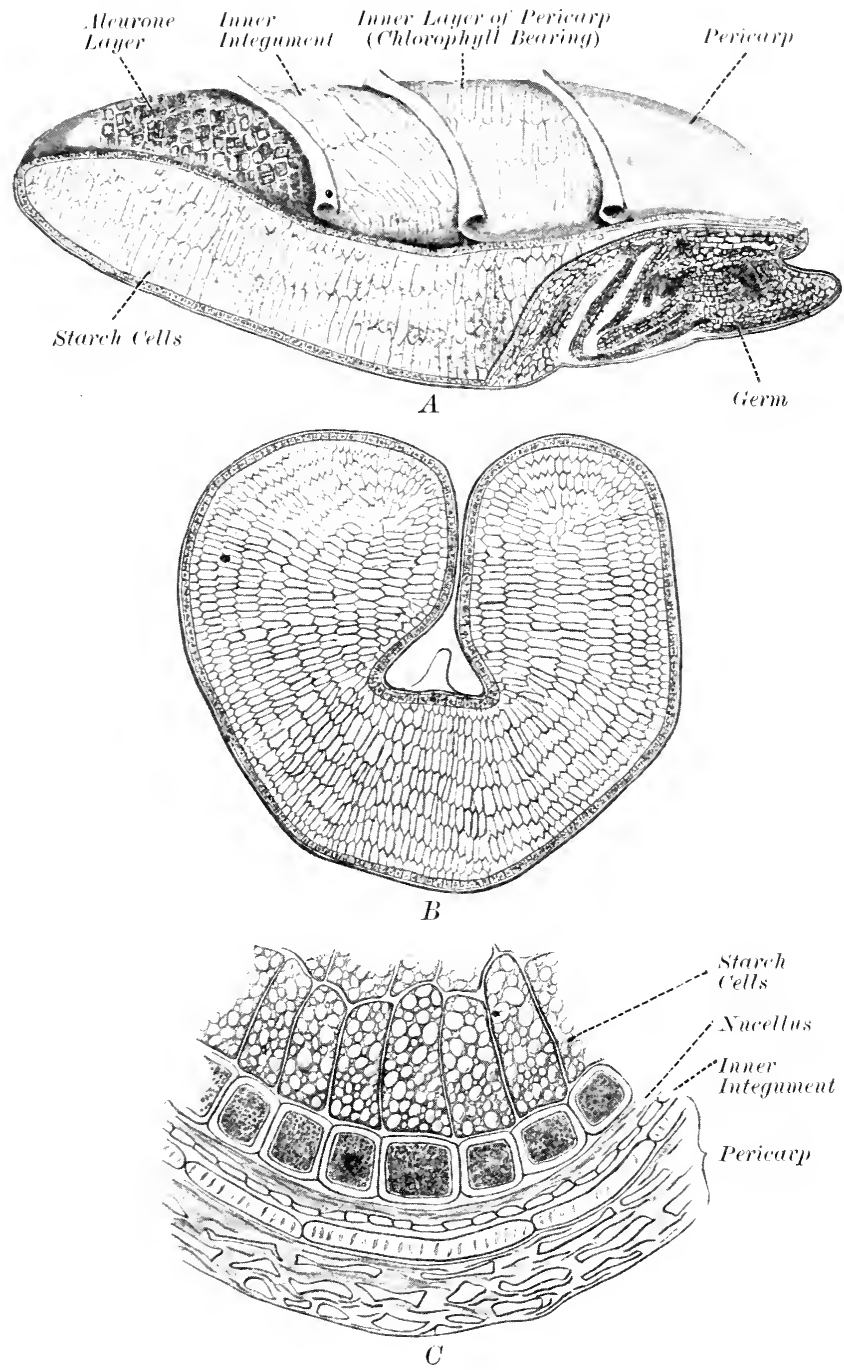

Fig. 5. Structure of the wheat berry: $A$, wheat berry cut through at the crease; $B$, cross section of the wheat berry; $C$, bran scale. Ordinarily a few starch-bearing cells arlhere to the inside of the bran 
hard winter wheat are due to environment, since this same variety, if grown in Illinois for example, soon loses its hard qualities and grades insteal as a "red" winter wheat.

The same is also true of spring wheats, the famous "No. 1 Hard spring" coming from the somewhat dry climate of the Dakotas, Minnesota, and the Northwest.

Northern wheats may be harder or softer than southern, though this quality seems to depend on soil and moisture more than on latitude.

Tenture. Texture and hardness are closely correlated. The texture is examined by making cross sections of the grain and is described as horny when it is found to be dark and vitreous in appearance, with no starch showing. (Ipposed to these are the grains which are white and starchy throughout. This is the characteristic appearance of the soft white wheats of the Pacific coast and Australia, while the horny texture is characteristic of the macaroni, all hard winter and spring wheats. Wheats of a homy texture are generally higher in protein content and produce a stronger flour.

Weiglit. The weight per measured hushel has always heen regarderl as of the greatest importance in judging the quality of wheat. In a general way it is true that a goor wheat never has a low weight per hushel, while a poor wheat is never high in weight.

Light weight may be due to immaturity, to premature dry weather or hot winds, or to the attacks of insects. The skin is wrinkled and not well filled out with starch. The weight of good wheat may he reduced hy exposure to inclement weather, when part of the grain is sprouted or is swelled and soaked by water until it never quite regains its normal size; or ly overheating in the statk, called stack 
burning; or ly piling up in lins when too damp, causing heat and mold.

Soundness. A good No. 1 wheat should have no sprouted, decayed, or injured grains from any ause, as exposure, stack burning, or moths. A No. 2- wheat might have a few discolored grains, but none sprouted. A No. :" wheat, if dry and in good condition otherwise, might contain a few sprouted grains. Howerer, the number of injured grains which may pass in a grade depends largely on how good the wheat was before suffering injury, the present dryness, etc, of the sample. Cirarling is always based as nearly as possible on the actual milling yuality of the grain.

Mustiness. This is caused usually hy dampness, either while the grain is in stack or lin. Musty wheat is almost worthless for flour, since the grain is permeated with a musty flavor. For this reason even a slight trace of mustiness is always discriminated agninst, even though the wheat may still le used for low-grale flour. Mustr grain is often worked into (hop) or some form of stork foorl.

Color. Wheat ranges in color from nearly a brick reed, through various shades of brown, to almost white. In a general way wheats from humid climates are light colored, while those of dry climates are dark. Some have a smooth, bright appearance, while in others the color is dull. Good wheat should not be bleached or in any way discolored, but should be generally bright, and in the hard wheats should have a vitreous appearance. The occurrence of "yellow berries" in hard wheats greatly depreciates their value, as they give a yellow color to the flour.

Stack burning gives wheat a dark and somewhat burnt appearance, exposure to weather produces a bleached and 
dull appearance, while orerheating in the hin usually gives a whitish aplearance and musty smell. Overheating in stack or bin often gives the germ end a dark color.

\section{Juming WheAT}

For the judging work first use the ten samples provided in the previous exercise. When these have been scored let the instructor go orer them carefully with the students, after which the class should have access to a good general collection of wheat samples. If possible the samples should be prorided in peck or half-bushel lots.

\section{Scoie Crord for Wrheat}

Variety Name

Number of Exhibit

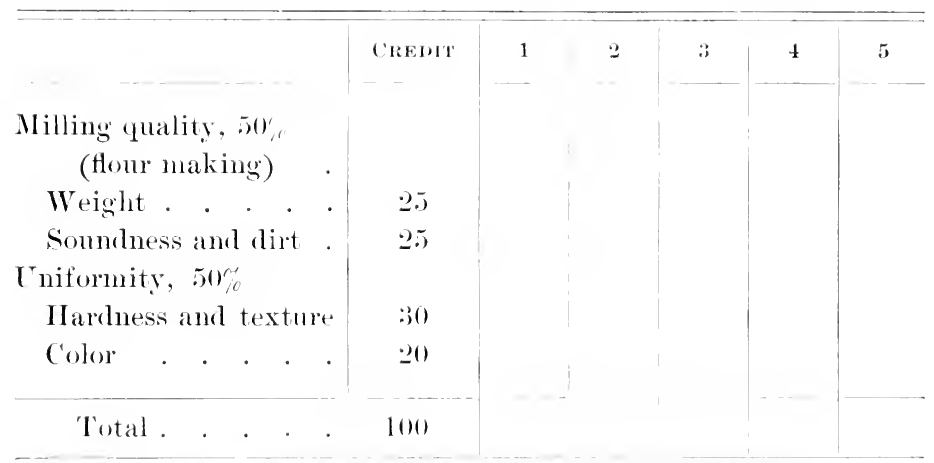

Student's Name

Ditte

\section{Explanation of Score C'erd}

In this score card wheat is judged entirely from the miller's stand point. If the wheat were being selected for seed, slightly different points might be considered, and the emphasis laid 
upon the above points in a different manner; but since so little is known as to just what constitutes a good seed wheat, outside of the miller's demands, and since the only important point, that of vitality, requires so much time to determine, it is thought best to judge the wheat from the miller's standpoint only.

Weight. Wheat should weigh sixty pounds per bushel. Cut two points for every jound below this. Other things being equal, a light wheat always contains a higher per cent of bran than heavy, and a lower per cent of patent flour.

Soundness and dirt. Sprouted, cracked, or unsound herries are worthless for Hour, and must either he separated out before grinding or the wheat used only for making medium or low-grade flours. Such grains are of little more value than weed seeds. Cut two points for every per cent of weel seeds and unsound grains.

Uniformity in hurdness and texture. Take alout a oneounce sample and divide it into three parts, _ (1) berries hard and vitreous, (2) berries soft and starchy, (3) berries intermediate. Let the class having the highest per cent in numbers or weight determine the classification of the sample. Cut one point for each per cent representing the other extreme, and one point for each two per cent of intermediate. (If the largest class is intermediate, then regard the other two classes as extremes.) In case of a fairly uniform sample it is often best to divide them into only two portions, cutting one point for each two per cent off.

Uniformity in color. In case of a mixture of colors cut two points for each per cent off color. (Yellow berries in hard winter wheat should be regarded as off color.) 

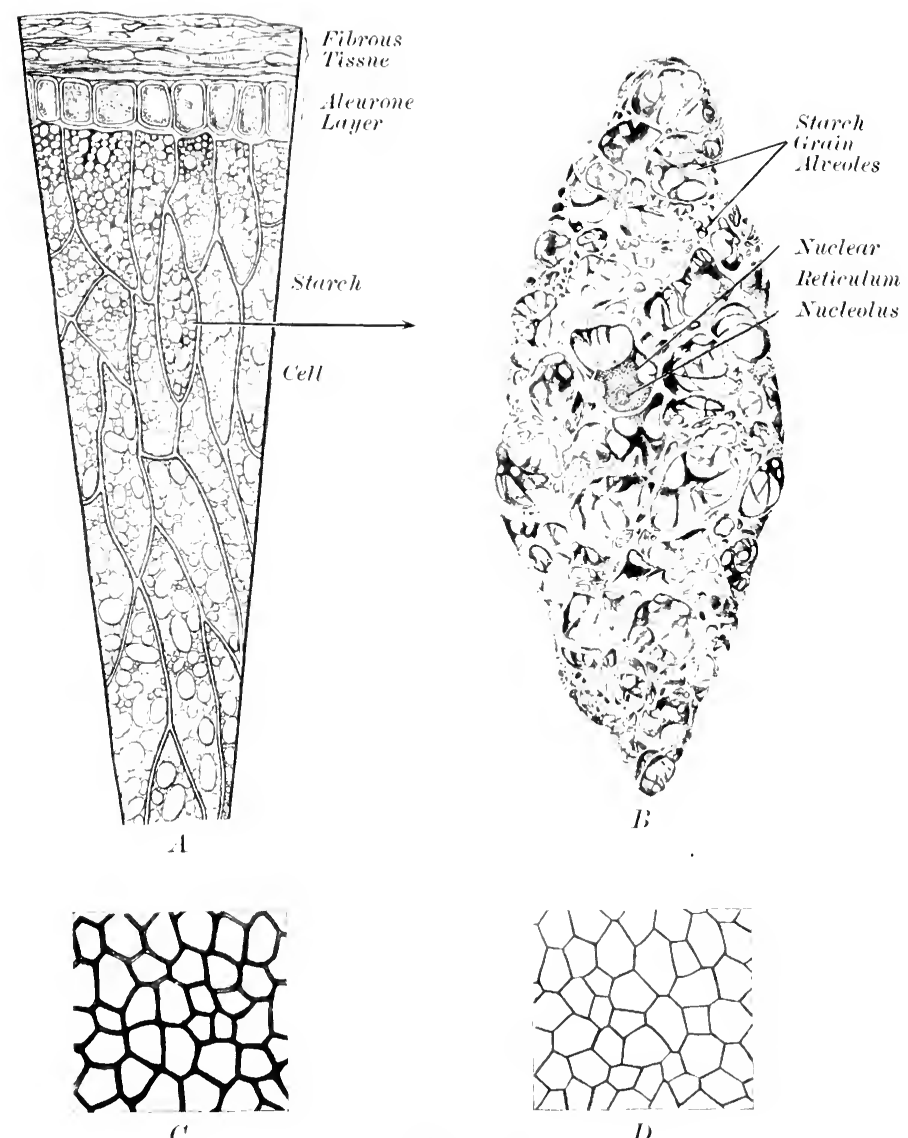

I)

Aleurone C'ells

Fig. 6. Structure of the wheat berry (after Cobb): $A$, section nearly to center of grain ; $B$, cellular tissue of starch-bearing cell; $C$, Tala vera de Bellerne, percentage area in cellular tissme, $29.8 \% ; D$, Belotourka, percentage area in cellular tissue, 18.2", 


\section{Determing the Glutes Contfast of Wheat}

The student should be provided with flow made from each of these five tyes of wheats, for the gluten test.

Weigh out thinty grams of flour made from a hard winter or spring wheat, and mix with enough water to form a stiff dough. After it has been worked into this condition allow it to stand for half an hour. Transfer the dough to a eloth and let a gentle stream of water run over it, working it meanwhile with the fingers. Continue the washing until no more starch is washed out, which is shown ly the water being clear when it runs away from the dough as it is being worked in the eloth or in the hand. Allow to remain in water.

Perform the same operation with a very soft wheat, as for instance, Sonora wheat from the Pacific conast. Compare the amounts of gluten from the two wheats.

\section{Commerchl Gimaterg of Wheat}

The student should use the same set of samples for the commercial grading work that he has used in judging, since he already has some knowledge of the relative merits of these wheats. At least a part of the samples should be ofticially graded.

The olject of this work is not primarily to learn what constitutes a grade, but rather to give the student a knowledge, based upon critical examination, of the qualities and characteristics of the common varieties and grades of wheat, both good and bad. 


\section{Wheat Inspection Rules ${ }^{1}$}

No. 1 Red Winter Wheat shall be pure Red Winter Wheat of both light and dark colors of the shorter-berried varieties, sound, plump, and well cleaned.

No. 2 lied Winter Wheat shall be Ried Winter Wheat of both light and dark colors, sound and reasonably clean.

No. 3 Red Winter Wheat shall include Red Winter Wheat not clean and phump enough for No. 2, but weighing not less than fifty-four pounds to the measured bushel.

No. 4 Red Winter Wheat shall include lied Winter Wheat damp, musty, or from any cause so badly damaged as to render it unfit for No. 3.

lied Winter Wheat containing a mixture not exceeding five per cent of White Winter Wheat shall be dassed as Red Winter Wheat.

Red Winter Wheat containing more than five per rent of White Winter Wheat shall be graded according to the quality thereof and classed as White Winter Wheat.

Hard Winter Wheat. The grades of Nos. 1, 2, 3, and 4 Hard Winter Wheat shall correspond in all respects with the grades of Nos. 1, 2, 3, and 4 Red Winter Wheat, except that they shall be of the Turkish variety.

In case of mixture of Turkish Red Winter Wheat with Red Winter Wheat, it shall be sraded according to the quality thereof and classed as Hard Winter Wheat.

No. 1 Northern Spring Wheat must be Northem-grown Spring Wheat, sound and reasonably clean and of good milling

1 Rules adopted by the Board of Railroad and IV arehonse Commissioners for the inspection of grain at chicago. 
quality, and must contain not less than 50 per cent of the hard varieties of spring Wheat.

No. 2 Northern Spring Wheat must be Northern-grown Spring Wheat, not elean enough or somnd enough for No. 1, and must contain not less than 50 per cent of the hard varieties of spring Wheat.

No. 1 Spring Wheat shall be somul, plump, and well aleaned.

No. 2 Spring Wheat shall be sound, reasonably clean, and of good milling quality.

No. 3 Spring Wheat shall include all inferior, shrunken, or dirty spring Wheat, weighing not less than fifty-three pounds to the measured bushel.

No. 4 spring Wheat shall include Spring Wheat, damp, musty, sprouted, badly bleached, or for any cause which renders it unfit for No. 3.

White Spring Wheat. The grades of Nos. 1, 2, 3, and $t$ White Spring Wheat shall correspond with the grades of Nos. 1, 2, 3, and 4 spring Wheat, except that they shall be of the White variety, or shall contain 5 jer cent or more of such White Wheat.

Frosted Wheat shall in no case he graded higher than No. 4, except that the grade of No. $?$ may contain as much of said Frosted Wheat as it is customary to allow of wheat damaged in any other way.

Mixed Wheat. The grades of Nos. 2 and 3 Mixed Wheat shall be equal in quality to the grades of Nos. 2 and 3 Red Winter Wheat, except that they shall inclucle mixtures of Spring and Winter Wheat.

In examining a sample of wheat it is well to take up each point, one at a time at first, as "hardness" or "texture," and 
examine the sample for this. Make a note of your observation in each case. After the sample has been carefully examined in this way make out a brief report on each sample, something after the following plan:

\begin{tabular}{|c|c|c|c|}
\hline $\begin{array}{c}\text { No. } \\
\text { SAMPLE }\end{array}$ & GRADE & $\begin{array}{c}\text { WEIGHT } \\
\text { PER BESHEL }\end{array}$ & REMARKS \\
\hline 1 & $\begin{array}{l}\text { - Hard } \\
\text { Winter }\end{array}$ & \} is lh. & $\begin{array}{l}\text { Horny texture, few } \cdot \text { yellow ber- } \\
\text { ries." }\end{array}$ \\
\hline$\stackrel{2}{-}$ & $\begin{array}{l}\text { :) Ried } \\
\text { Winter }\end{array}$ & \}.$i t i 11$. & $\begin{array}{l}\text { Many bleached kernels, lacks } \\
\text { plumpness. slightly musty. }\end{array}$ \\
\hline
\end{tabular}

\section{Testraci Wheat for Perity}

Standard for purity 99 per cent.

Take ahout a half-pint sample and spread on a table, carefully separating all impurities, as weed seeds, straws, etc. Then find by weight the amount of pure seed and foreign matter, and calculate per cent of purity.

Examine the foreign matter carefully and identify the varieties of ween seeds found.

\section{Testiver Wheat for Viability}

Standard for germination 95-98 per cent.

If taking the sample from a hin, do not take it from one spot, but thoroughly mix several shovelfuls, and then take out a small sample and take from this at random 100 grains. Place in moist chamber, as described on page 94 , and moisten laily. Keep as near as possible at a temperature ranging from $s 0^{\circ}$ to $90^{\circ} \mathrm{F}$. (remmation should hegin in three days and be complete in ahout six. 
When the radicle has reached a length of one fourth inch or more the germination is sutficient. Remove the sprouted grains daily until germination has ceased, then hy counting the number of grains left and subtracting this number from 100 you have the per cent of germination.

\section{STUDY OF VARIATION IN WIEAT PLANTS}

This exereise is valuable to illustrate the natural variation found in all kinds of plants, and also in showing the value of the "inclividual plant method" of selection for pure seed or imploved strains.

The plants are grown by planting one seerl in a place, six inches aprart each way. When the plants are mature they are pulled up' and laid away. The class should work orer as large a number of plants as possible, but not less than 100 . The following data should be olntained for each plant:

1. Number of spikes per plant.

2. Average length of spikes per plant.

3. Average number of herries per spike.

4. Number of berries per plant.

5. Weight of herries jer plant.

6. Average weight of berries per spike.

7. Weight of 100 herries.

8. Average weight of berry per plant.

A convenient form for recording the properties of 100 plants may be found in the table on the following page.

After all plants have been examined the following general correlations should be worked out:

1. Correlation between number of spikes per plant and average length. 
2. Correlation between number of spikes per plant and average weight of grain per spike.

3. Correlation hetween number of spikes per plant and total vielel of grain.

4. Correlation hetween total yield of grain and size of berry.

This is most easily earried out by arranging the plants accorting to the characteristies for which a correlation is wanterl. For example, arrange the wheat plants according to number of spikes per plant, or according to yield per plant. After such an arrangement the correlations may he made still more graphic hy platting the curves on coörlinate paper.

\begin{tabular}{|c|c|c|c|c|c|c|c|c|}
\hline 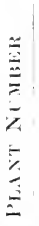 & 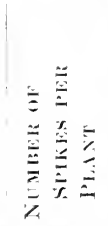 & 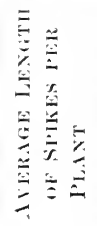 & 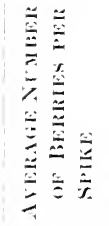 & 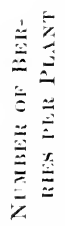 & 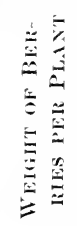 & 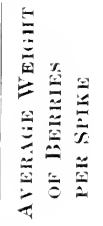 & 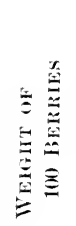 & 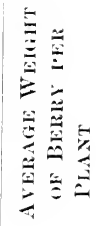 \\
\hline 1 & & & & & & & & \\
\hline$\ddot{2}$ & & & & & & & & \\
\hline$: ;$ & & & & & & & & \\
\hline 4 & & & & & & & & \\
\hline . & & & & & & & & \\
\hline & & & & & & & & \\
\hline
\end{tabular}

BLLESTONE OR COPPER-SLLPHATE TREATMENT FOR STINKING SMLT OF WIEAT

(Prepared by A. N. Hume, University of Illinois)

Immerse the seed for ten minutes in a solution of copper sulphate at the rate of one pound to five gallons of water. Allow it to stand for ten minutes in a hag or hasket to 


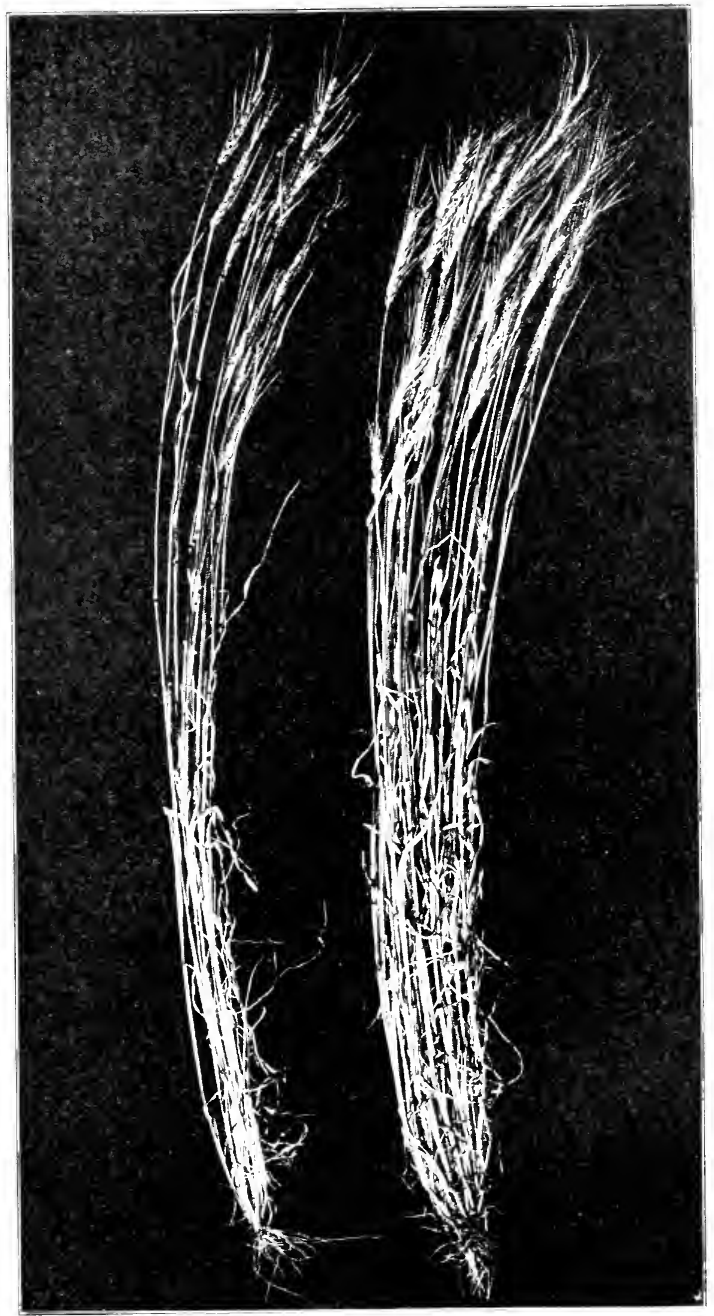

Fu. T. Natural variation fonnel in wheat plants grown muler mniform eomlition. These two planti were taken from a bed where the plants were planterl one in a place, (i inches afalt catch way 
hrain, and then speanl and hry. ()r the seed may be sprinkled at the rate of one gallon of the solution to four bushels of grain, sprinkling and stirring until thoroughly wet. It the end of an hour drẹ.

Treat a sufficient prantity of seed wheat hy either one of the abse methods.

Test doplicate simples of 100 kernels of treated and untreated seed and rejort as follows:

Treated Seed

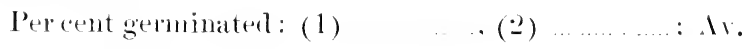

Uintreated steed

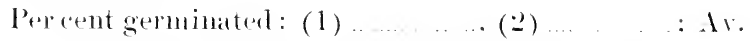

lors the treatment injure the vitality of the seed?

student is Xame

Date

\section{PNOPERTY LDPRARY \\ N. C. State College}




\section{SECTION II-CORN \\ (LASTIFICATION OF SPECIES}

The different groups of com are chassitied as follows:

()riter

(iemus

speecies

(iroll) crominimente

Z'"1

$1 /(1) \times *$

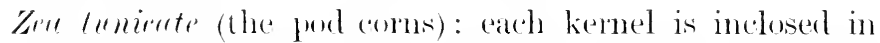
a pod or husk, and the ear inclosed in husks; rare; very leafy, hence called "cow comm."

Z. ererto (the jop corms) : characterized hy the excessive proportion of corneous endosperm and the small size of the kernels and ear. Kernel is pointed-oval in form. The best popping varieties are corneous throughout. Poplping is caused hy the explosion of contained moisture on heating.

Z. indurete (the flint corns): characterized by starchy endosperm inchosed in corneous endosperm. They are oval in form. In some varieties the eorneous portion is very thin at top and a slight indentation apjears.

Z. indentata (the dent corms) : characterized by corneous endosperm at the sides of the kernel, the starchy endosperm extending to the summit. By drying and shrinkage of the starchy matter the summit of the kernel is drawn in or together and indented in various forms. The kernel is long and wedge-shaperl. Most extensively grown and has largest number of varieties. 
Z. amylaced (the soft corns) : characterized hy the alsence of corneous emblosperm; all starehy ; no indentation; shrinks uniformly; shaped like flint but soft.

$Z$. sucharata (the sweet corns): characterized by the translucent, horny alnearance of the kernel, and the more or less wrinkled or shriveled condition; shrinking due to change of stareh to glucose: werlge-shaperl kernel.

\section{Tricties of Corn}

The so-ealled varieties of corn, like those of wheat, are very numerous.

Varieties of the dent type are most commonly grown in this country.

Flint corn ripens carlier and is aclapted to the more northern latitudes.

Ient com grows langer and vields heavier.

While there are 11 monems so-ealled varieties, there are only a few distinct and recognized hreeds of miform eliaracteristics.

Owing to the ease with which varieties are produced, each locality generally has varieties peculiarly adapted to it.

\section{LABORATORY NTIM OF SPEOLE ANI) OF ('HARAC'TERS}

\section{EXIMINATION OF SPECHS}

Samples on the stalk of the various types of corn are provided.

For each of the six principal groups of corn carry out the following outline : 
Describe a typical ear as to color, shape, indentation and depth of grain, length, ete.

Make drawings of both longitudinal and eross sections of grains, showing hy appropriate sharling where the germ, the starehy

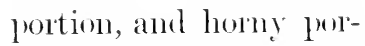
tions of the kernel are located.

TERys FoR InECRHANG

\section{Colix}

The value of this exercise is to enable the instructor to fix the meaning of the technieal terms used in describing an ear of corm. For example, the terms "deep inclentation," or "wedge-sha ped," may" convey different meanings to different students. If the class all have a common understanding of these terms
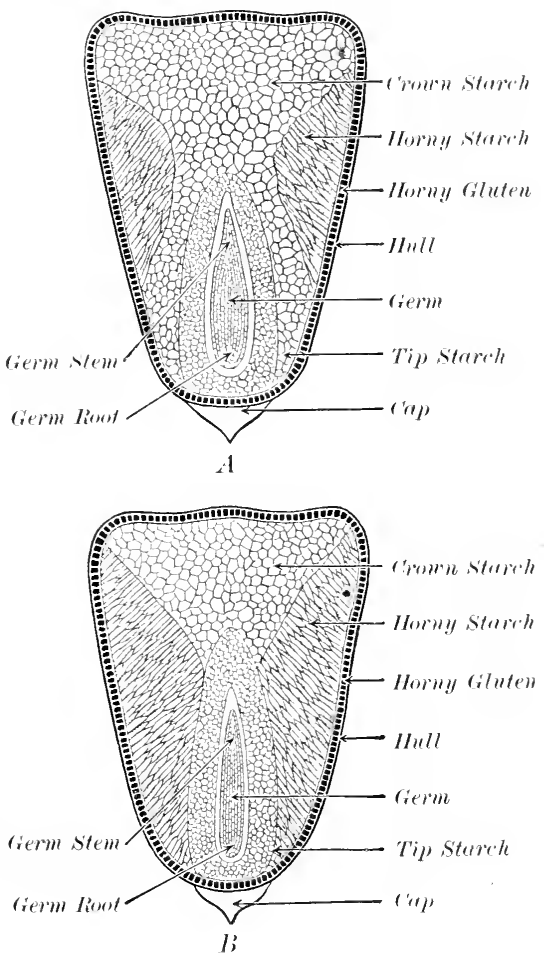

Fis. 8. A, low-proteid corn kernel; $l$; high-proteid corn kernel

the regular work of eorn judging is then much simplifien.

Give each student an ear of corn and have him describe it by filling out the outline on page 32. Eight or ten ears should be described in this way. 


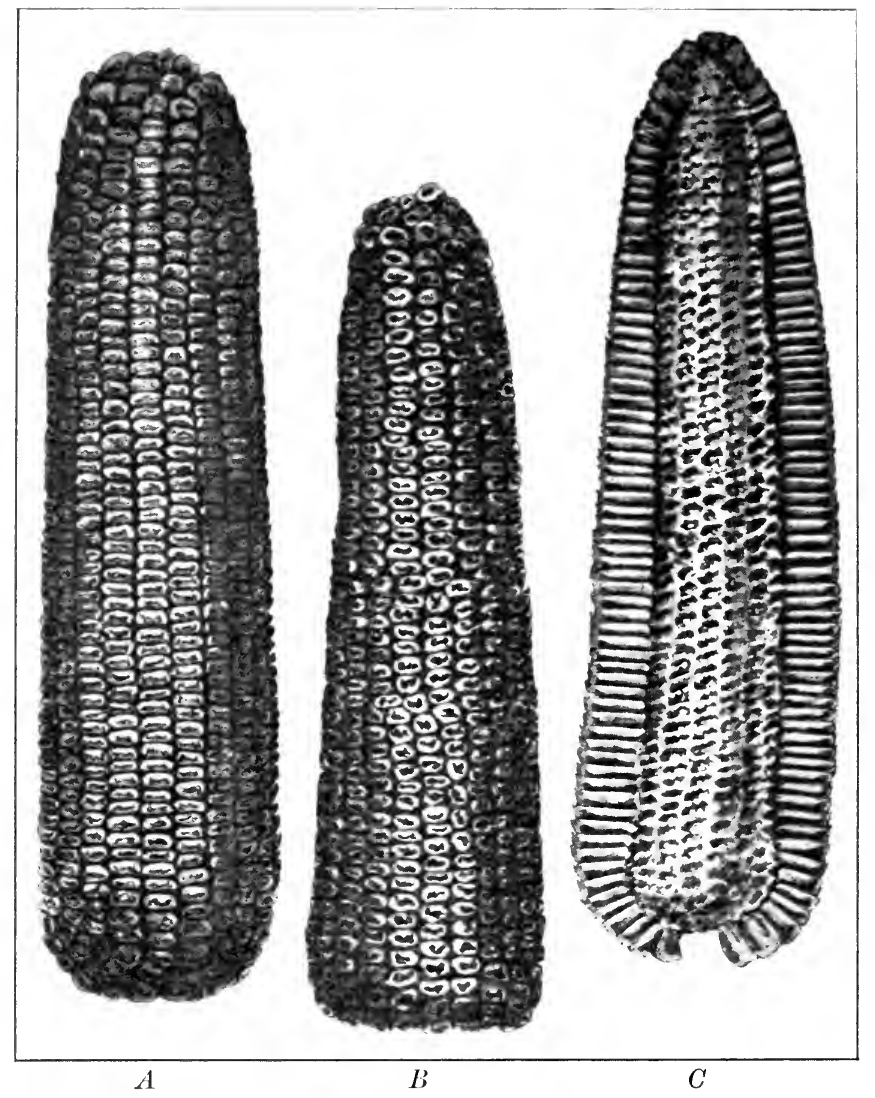

Fic. 9. Typical ears of corlu: $A$, cylindrical ear; $B$, very tapering ear, rows dropping ont; $C$, tapering ear, kemels becoming shorter toward the tip 
Shape of Ear

Cylindrical (Fig. 9, 1).

Tapering (Fig. 9, (').

Very tapering (Fig. !) li).

Length of Eat

Long (over 10 inches).

Medium (s to 10 inches).

Short (under $s$ inches).

Circumference of Eal

Large (over $s$ inches).

Medium (6 to $s$ inches).

small (under 6 inches).

Color of Kermel

Yellow.

Variegater.

IVhite.

Rerl.
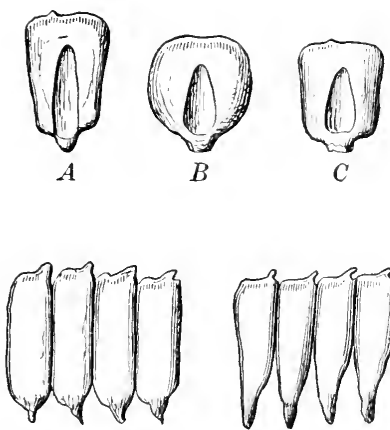

I)

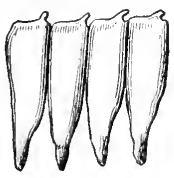

E:

Fig. 10. A, wedge-shaped kernel; $B$, round kernel; $C$, square kernel; $D$, edge view of kernels fitting close at tips ; $E$, kernels with wide spacr at tip

\section{Indentation of Kernel}

sinooth.

Dinplerl.

deejly dented.

shape of Kernel

Wedge (Fig. 10, A).

Round (Fig. 10, B).

square (Fig. 10, (').

Parallel-sidel (Fig. 10, D)).

Pointed (Fig. 10, E).

Lemgth of Kemel

long (Figs. 12, A, and 16, l').

Merdium.

short (Figs. 12, Is, and 16, 1).

Nimulare of Rous of Kermels

Mamy (20 or more).

Merlimm $(1+$ to 200$)$.

Few (muler 1t).

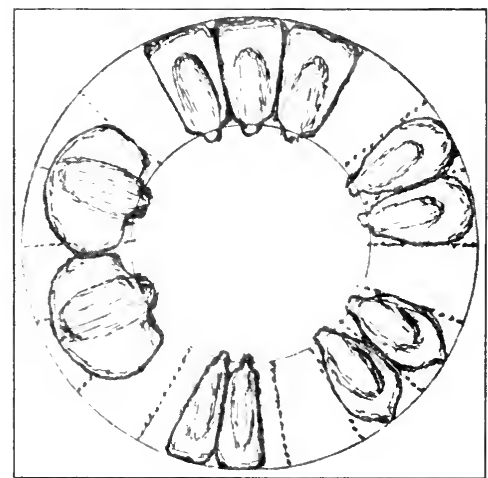

Fif. 11. A study of kernel types (Wichigan Bulletin, 34) 


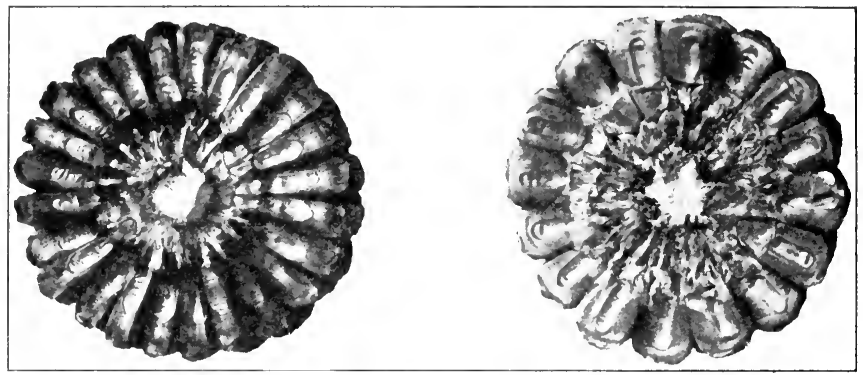

A

I)

Frs. 12. 1)eep- and shallow-kerneled corn: $A$, long kernel, small cob; $B$, short kernel, large cob

space between Roms

(at crown of kermel)

Wide (Fig. 11).

Close (Fig. 11).

(at coh)

Close (Fig. 11).

Wide (Fig. 11).

Arrangement of Rou's

Distinct.
Paired. $\left\{\begin{array}{l}\text { In some corn the } \\ \text { rows seem to birs, while in } \\ \text { others the rows are } \\ \text { all separate. }\end{array}\right.$

Тїм

Covered (Fig. 13, F').

Exposed (Fig. 1:3, 1). sivell of Butt

Deeply rounded (Fig. 1:), E).

Moderately rominder.

Flat (Fig. 1:3, I)).

\section{Size of Butt}

Enlarged (Fig. 9, B).

[niform (Fig. !, 1).

Size of shomk

Sinall (Fig, 1:) C).

Medium (Fig. 1:3, E).

Large (Fig. 1:3, I)).

size of Cols

small (Fig. 12, 1).

Medium.

Large (Fig. 12, B).

Color of c coll

Riel. White.

For this exercise select ears or kernels that possess each of the characters mentioned under each head. 

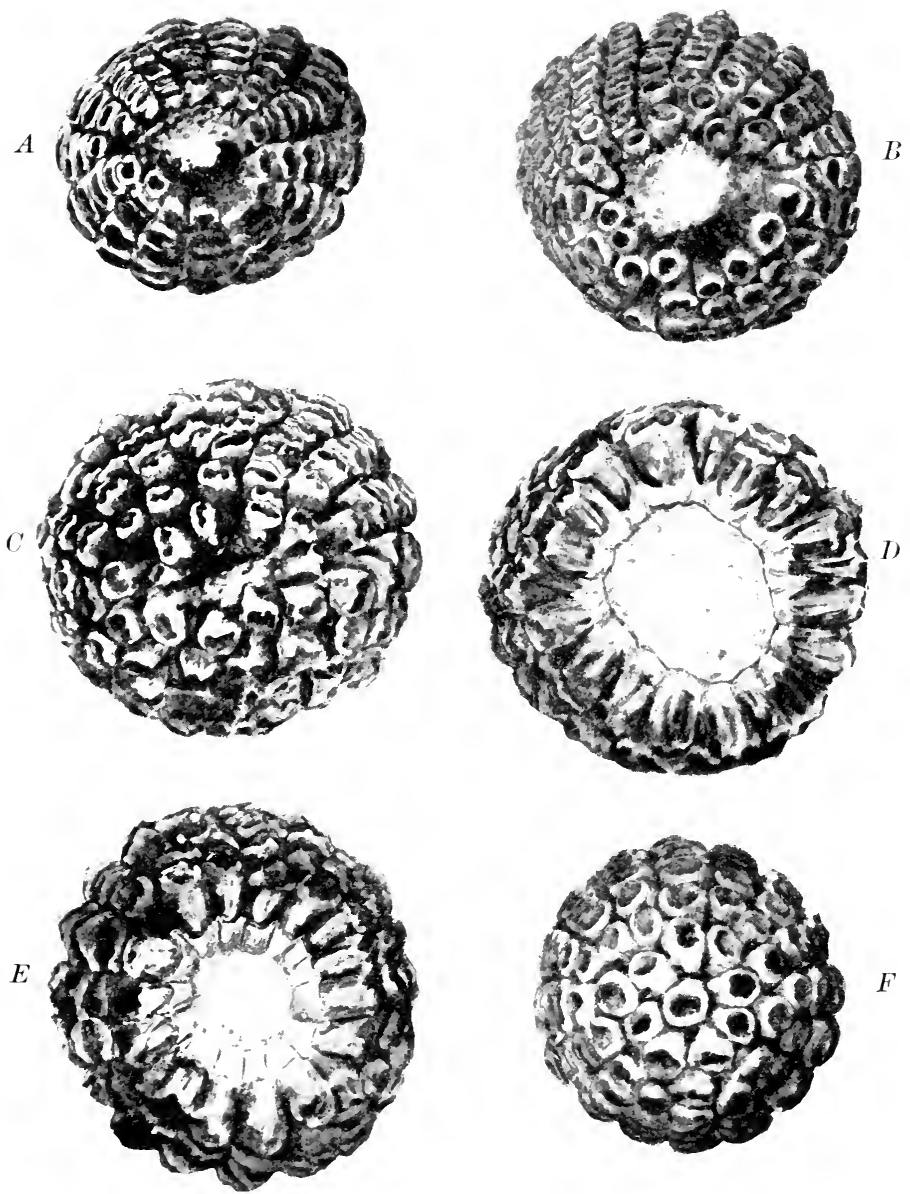

Fif. 19. $A$ and $D$, poor tips, too much exposerl ; $C$, poor butt, shank too small; 1), joor butt, shank and cob tou latrec; $E$, ideal butt; $F$, ideal tip 


\section{Ontlate FOR DEscribing CORN}

Variety Name

Ear

Shape

Length

Circumference

Kernel

Color

Indentation

Shape

Length

Romes

Nomber

space

At cal'

At $\mathrm{col}$,

Student's Name
Number of Sample. Arrangenent

Tip

Butt

sivell

size

sillank:

size

(a)

size.

Color

\section{Comparatere stery of Characters}

The student should he provided with a ten-ear exhihit. Selecting some part, like the tip of the ear, first arrange the ears according to tips, placing the hest tip at the right, then the next best tip, and so on, the porrest finally being on the extreme left.

The following order of sturly is suggested:

1. Place ears aceording to tips.

2. Place ears accorting to liutts.

3. Place ears according to shape.

4. Place ears accorling to indentation. 
5. Place ears accorling to shape of kernel.

6. Place ears according to space between rows.

7. Place ears according to market conclition.

8. Place ears having both best butt and best tip.

9. Place ear first having best butt, tip, and shape, and so on down.

Continue the arrangements, acling one new part each time, until the student finally places the ears first, second, third, etc., when all parts are taken into consideration.

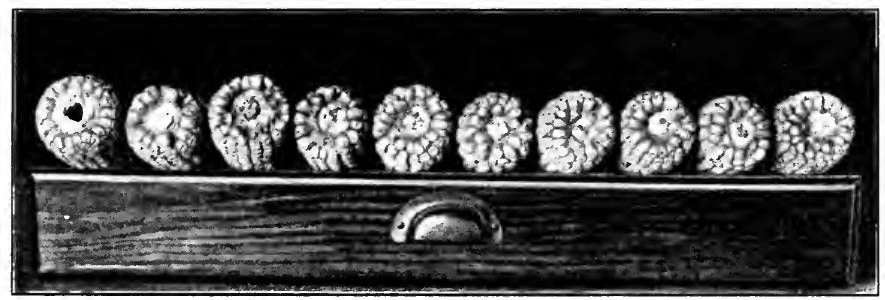

Fur. 14. A ten-ear exhibit of corn, and the box in which it is kept. The ears are placed from right to left, according to the quality of the butts. This illustrates the method of making a comparative sturly of some one character

\section{JUDGING CORN}

The operation of judging corn is an attempt to estimate numerically its value for seed. The principle involved is that an ear of corn when planted reproduces more or less closely its own characters in the resulting ears. By selecting for seed ears of uniform size, deep kernels, and other desirable characters, the production of nublins, shallow kernels, and other objectionable characters is diminished, and the productiveness correspondingly increased. 
Two types of score cards are shown, either of which may be used in judging. Each of these earts is typical of a system

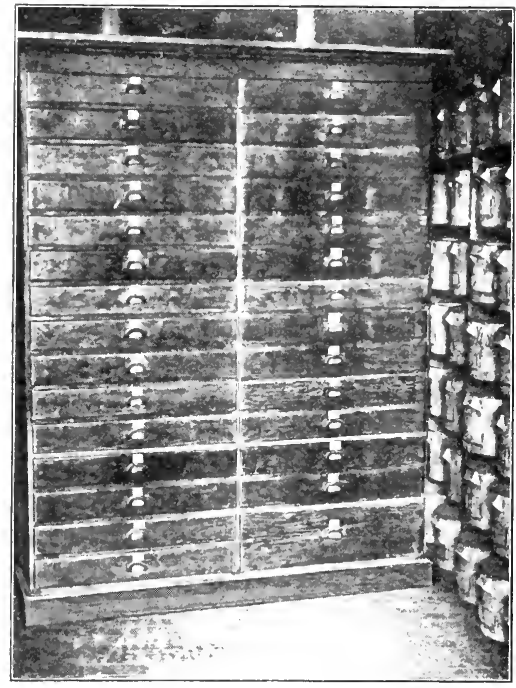

Fur. 15. A case nsed in keeping the tenear exhibits of corn for juctging of judging adapted to the production of corn under certain conditions. The essential difference is that score Card No. 1 is designed to discourage the production of a thick cob, chiefly because it retards drying of the grain in the fall, and thus makes the late-maturing corn likely to be injured by flost.

Seore Card No. 2 is adapted to a region of light rainfall and dry atmosphere, where the grain dries out readily in the fall, and where a thick cob is supposed to accompany drought resistance in the corn. Both ands favor a deep kernel.

\section{Prints to be chseried}

Iriformity of Exhibit. The points that go to produce miformity of exhibit are size, shape, and color of ear, appearance of tips and lutts, and indentation of kernel. The ears should closely resemble each other in these characters; in other words, each ear should look as much as possible like every other ear. In ansidering this point the judge is not 
called upon to decide as to the desiratility of the characters possessed by the different ears, hut solely as to their similarity.

The judge places the ten ears side by side on a table or bench with the buts towards him. He then, by removing one ear and replacing it hy another, sorts over the exhibit until he has the similar ears lying sicle by sicle. If there are six similar ears of one tyle and four of another, he credits the exhibit with six similar ears, even shomld these not be so desirable as those of the other type.

Trueness to Type. Each variety of corn has, or shomld have, its character sufficiently constant and well marked to enable any one acplainted with the variety to recognize it. The combination of characters gives type to the variety. In julging trueness to ty pe the ears possessing all of the variety characters to an monistakable degree are credited with being true to tyje, while those failing in this respect are discarded.

shope of Eurs. Leaving the exhibit arrangerl as before, count the number of ears that are cylindrical or nearly so. Credit the exhibit with such ears only. A cylindrical ear is desirable because it permits the growth of kernels of uniform shape, and swch ears generally have a larger proportion of corn to cob. A tapering ear must have kernels becoming smaller from butt to tip, or else must drop out one row or more letween the luntt and tip. In either case barly shaped and small kernels are produced.

c'olor of Cols. The color of the col) is, to some extent, a guide to the purity of breeding of the exhibit. The presence of a white cols in an exhibit of otherwise red cols is an indication that at some time there has leen a cross with a white-col variety. This may have occurred many years 
before, and may not he a present detriment to the corn, lut, on the other hand, it may be detrimental and for that reason is discountenaneed. The same is true of the presence of a red cob in an exhibit of otherwise white ones. Some varieties of com having white kernels have red cobs, but in such a case there should be no white cobs in the exhibit.

Color of Kernels. A yellow kermel on a white ear or a white kernel on a yellow ear shows that the corn has been fertilizer by pollen from corn of another color: in other words, it shows that the variety is not strictly pure. The cross fertilization may have oecurred in the year in which the ear was raised or it may be of earlier date; there is no way of distinguishing, but the fact is equally objectionable in either case.

Each kernel on the ear results from the fertilization of its ovary hy pollen from the same plant or some other. The pollen is borne on the tassel. If any ovary is fertilized hy pollen from corn of a different color, the resulting kemel will he of a different color from the rest of the ear.

A mixed liernel on a yellow ear may he rearlily seen, as the erown of the kernel is white. On a white ear the crown of a mixed kernel hardly shows the yellow color, but it may be seen on the part of the kernel beneath the crown. They are, therefore, harder to discover, and the judge must look very carefully.

Market Condition. The market condition of corn depends most largely upon its ripeness. other conditions, such as freetom from smut or worms, and brightness of color, also enter into consideration to some extent. The degree of maturity is commonly determined by the firmness or looseness of the kernels on the eol, and by the stiffness of the 
cob. Take in turn each ear in the hand and attempt to twist it. If the coln twists readily it is not well matured. If the cob is stift, see if the kemels are lonse on the cob. Looseness of the kennels indieates immaturity.

Tips of Eurs. The tips of the cols are very likely to protrude beyond the kernels. The extent to which this occurs will vary with the season and with the strain of corn. The tips are considered in selecting corn for seed because, being the last part of the ear to throw out silk, there is a possibility that the strain may acyuire the habit of developing the tip silk too late to be fertilized, should ears without tip kernels he continually selected for seed.

On the other hand it is argued that, in the main, tijs that are well filled out are fomml on ears of less than arerage length, and that their selection for seed must result in shortening the ear. Howerer, where seed cars are required to be of a certain length, it is clouhtful whether this argument will hold.

Butts of Errs. As the icleal ear is cylindrical in shape the butt should be miform in liameter with the rest of the ear. It should be well rounded and symmetrical, the rows extencling in a uniform way well over and around the shank. The butt should not be expanded or enlarged, since this usually goes with an ahnormally large shank, which makes husking more rlifticult. The expanded hutt is generally due to an enlargement of the coh, and is not well filled over, while the kernels are short and irregular, thus reducing the percentage of corn. On the other hand, the hutt may be contracted or filled over too far, in which ease the shank is apt to be too small, increasing the tendency of the ears to drop off before husking time. 
Uniformity of Kernols. The kernel shape varies with varieties, but whaterer the shape, if the corn is a wellselected variety, the kernels should be similar. In judging for uniformity, tirst remove two kernels from near the middle of each ear and lay them near one end of the ear, with their tips toward you. Place the ears and pairs of kernels side by side, when the comprarative size, shape, etc., of the different pairs of kernels may be noted.

The indentation of the kernels is hest comprared on the ears. Count the number of ears having kernels which are in a general way uniform and score the exhibit accordingly.

Sher of himels. In general the shape of the kernel should be that of a wedge, as this shape permits the greatest amount of corn on the cols. The kernels should be of such shape that they fit snugly from tip to crown. If they are too wedge-shaped there is a loss of space at the tips, while if they are too rectangular there will be wide spaces between the rows at the crown. The kernels should not be too thin at the tip, but should be about the same thickness as at the crown. Pointed, thin kernels are often low in vitality and of less feeding value than kemels having plump, well-developed tips. In jurlging the shape of kernels, remove a few from near the middle of the ear in order to enable you to exanine the sracing letween the tijs and crowns of those remaining on the ear, and to note how closely they fit.

The length and indentation of the kemels should also be noted. A gool indentation is of importance, since a deep inclentation seems to go with a cleep grain. In pieking seed ears, only well-indented ones should be selected, as this is the only practical way of keeping ul a good depth of liernel. 
Sprece betucen Kirmels. The space between kernels is closely correlated with their shape. Well-shaped kernels shomld have no lost space between rows, either at tijs or crowns. In examining spaces between rows, remore sereral kernels near the middle of the ear and examine the slace hetween tips of kernels both when looking at the side of the row and when looking at the ends. Then examine the spaces hetween lows at the top of kernels; this should, as a general thing, he less than one thirty-second of an inch, thomgh this rule canmot be rigidly observed. Too much space is not only assoeiated with poorly shaped and irregular kernels but also with a decreased percentage of corn.

Length of Errs. The length of ear varies with the available fertility of the soil, the amount of moisture, the total heat units included in the growing seasom, and also with the variety of corn and its hereditary tendeney. It is, therefore, influenced in a measure by the seed, and for that reasom an ear of desirable length is farored ly one of the score cards. The other card does not call for an ear of a certain length, because it is designed for a region in which the distance of a few miles makes a great difference in the size of the ear it is possible to raise, and that it is desirable to select for seed. Even in a region of good rainfall the length of the ear will vary with the latitude, and it is not reasomahle to expect a variety to produce as large ears on the nuthern edge of the corn belt as it does farther sonth. It will be necessary therefore to have different standards for different localities.

Circumference of Ears. This is determined by the depth of the kernel and the thickness of the coll. The depth of kernel is influenced by the number of heat mits in the growing season, by the amount of available fertility and moisture in 
the soil, and by inheritance. A deep kernel is desirable because it gives a greater yield of grain than does a shallow kernel. The depth of the kemel that can be raised in any region is limited by the length and temperature of the growing season. While, therefore, a deep kernel is desirable, it should not be so deep that it cannot mature completely in the ordinary growing season of that region. In a humid climate a thin cob is desirable, while in a dry climate a large cob is considered preferable. In Score Card No. 1 the circumference prescribed is as small as is considered consistent with a deep kernel. In score Card No. 2 no value is given to this point.

Proportion of Corn on Ear. The reason for determining this point is primarily to discourage the production of a large cob, while it also encourages a deep kernel. The effect of this point in connection with the following one is to prevent the growth of an ear unduly large in circumference in proportion to its length.

The proportion of corn on the ear is determined by weighing three representative ears of the exhibit, shelling the grain, and reweighing the cobs. The difference between these weights divided by the weight of the ears gives the per cent of corn on the ear.

Weight of Com on Ear. While a very large ear of corn is not, under all conditions, desirable for seed, it is to be desired. that an ear of a given length should possess a maximum quantity of grain. By requiring an ear of given length to shell out a certain weight of grain a deep kernel is placed at a premium, as is also a heary kernel. The danger of producing a deep but light-weight kernel is thus avoided.

It is well understood that a deep kernel requires a long growing period for its development. Should the growing 
season not be favorable, or should the attempt be made to raise a type of corn having a kernel too deep for the climate

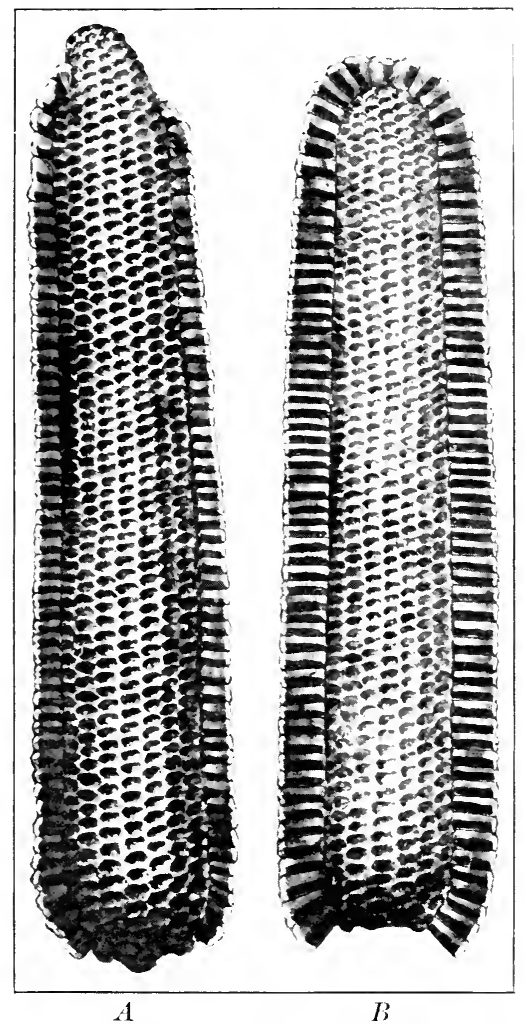

Fig. 16. Typical ear's: A, shallow-kerneled ear; $B$, deep-kerneled ear

in which it is planted, the result would be a comparatively deep but light-weight kernel. To discourage this the weight requirement is marle. 


$$
\text { Score Card for Corn, No. } 1
$$

(Adopted by the Iowa Corn Growers' Association)

Variety

Number of Exhibit

\begin{tabular}{|c|c|c|c|c|c|}
\hline & & & VALUE & $\begin{array}{l}\text { STUDENT'S } \\
\text { SCORE }\end{array}$ & $\begin{array}{l}\text { CORRECTED } \\
\text { SCORE }\end{array}$ \\
\hline Trueness to type. &. & . & 10 & & \\
\hline shape of ear & . . & 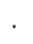 & 10 & & \\
\hline Color of kernels. . & . . & . & 5 & & \\
\hline Color of col . . . & .. & . & 5 & & \\
\hline Vitality, or seed condit & tion & . & 10 & & \\
\hline Tips of ears . . . & . . & . & 5 & & \\
\hline Butts of ears. . &. & . & 5 & & \\
\hline Eniformity of kernels & . . & . & 10 & & \\
\hline Shape of kernels. & .. & & 5 & & \\
\hline Length of ear. . & . . & & 10 & & \\
\hline Cireumference of ear & $\cdot$. & & 5 & & \\
\hline Furrow between rows & . . & & 5 & & \\
\hline space between kernels & at col & & 5 & & \\
\hline Proportion of corn to $c$ & ob . & 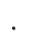 & 10 & & \\
\hline
\end{tabular}

Student's Name

Date

Rules for Judging Exhibits of Corn (Score Card No. 1)

Trueness to Type. The ten ears in the sample should possess similar or like characteristics and should be true to the variety which they represent.

Shape of Ear. The shape of the ear should conform to the variety type. Ear should be full and strong in central portion, and not taper too rapidly toward the tip, indicating strong constitution and good yield.

Color of Kernels. Color of grain should be true to variety and free from mixture. For one or two mixed kernels a cut 
of one-fourth point should be made; for four or more mixed kernels, a cut of one-half point. Inifferences in shade of color, as light or clark red, white or cream color, must be scored according to variety characteristics.

color of coh. An ear with white col, in yellow corn or red coh in white corn should be disqualitied or marked zero. This mixture reduees the value of the enrn for seed purposes, indicates lack of purity, and tends toward a too wide variation in time of maturity, size and shape of kernels, etc.

Vitulity, or Sced Condition. Corn should be in good market condition and should show good constitution, heing capable of frolucing strong, vigorous growth and yield.

Tips of Eurs. The form of tip should be regular: kernels near tip should te of regular shape and size. The profortion of tije covered or filled must he considered. Long, pointed tips, as well as blunt, flattened, or double tips, are oljectionalile.

Butts of Ears. The rows of kernels should extend in regular orter over the butt, leaving a deep depression when the shank is removed. Open and swelled butts, depressed and flat butts with flattened, glazed kernels, are objectionalle, and must be cut according to the judgment of the scorer.

Cniformity and shape of Kornels. The kernels should he uniform in size and shape, making it possible to secure uniformity in dropping with the planter, and consequently a good stand. The kernels should also be not only uniform on the individual ear but also uniform with each ear in the sample. They should also be uniform in color and true to variety type. The kernels should he so shaped that their edges touch from tip to crown. The tip portion of the kernel is rich in protein and oil, and hence of high feeding value. Kernels 
with a large germ insure strong, vigorous growth, as well as richness in quality of kernel.

Lenyth of Eur. The length of ear varies aceording to variety, type, and the characteristics sought for by the individual breeder. Uniformity in length is to be sought for in a sample, and a sample having even length of ears should score higher than one that varies, even if it be within the limits. Tsual length of ears for northern section of state, $8 \frac{1}{2}$ to $9 \frac{1}{2}$ inches; central section, $8_{4}^{3}$ to $9 \frac{3}{4}$ inches; southern section, 9 to 10 inches. Very long ears are objectionable because they usually have poor butts and tips, hroarl, shallow kernels, and hence a low percentage of corn to coll.

Circumference of Ear. The points made on length of ear, differing with variety tyes, hold true also in circumference of the ear. The circumference of the ear should be in symmetry with its length. An ear too great in cireumference for its length is generally slow in maturing, and too frequently results in soft corn. I)imensions for the northern section of the state are $6 \frac{1}{2}$ to 7 inches; central section, $633_{4}^{3}$ to $7 \frac{1}{4}$ inches; southern section, 7 to $7 \frac{1}{2}$ inches. Measure the circumference at one third the clistance from the luntt to the tip of the ear.

Furrows between Rous. The furrows between the rows of kernels should he of sufficient size to permit the corn to dry out readily, but not so large as to lose in proportion of corn to col).

Space betwen Tips of Kermels at Coll. This is very oljectionable, as it indicates immaturity, weak constitution, and poor feeting value.

Proportion of Corn to Cob. The proportion of corn is determined by weight. Dejth of kernels, size of cob, maturity, 
furrows, and space at cob all affect the proportion. In letermining the proportion of corn to cob, weigh and shell every alternate ear in exhibit. Weigh the cobs and subtract from weight of ears, giving weight of corn; divide the weight of corn by total weight of ears, which will give the per cent of corn. Per cent of corn should be from 86 to 87 . For each per cent short of standard a cut of one and one-half points should be made.

Each sample should consist of ten ears of corn.

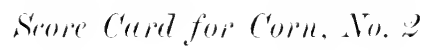

Variety Name.

Number of Exhibit

\begin{tabular}{|c|c|c|c|c|c|c|}
\hline & & & & VALTE & $\begin{array}{l}\text { STIDENI'S } \\
\text { SCORE }\end{array}$ & $\begin{array}{c}\text { Corrected } \\
\text { SCORE }\end{array}$ \\
\hline Lniformity of exhibi & & . & . & 10 & & \\
\hline Shape of ears. . & & . & . & 10) & & \\
\hline Color of cols. . . & & . & . & $\therefore$ & & \\
\hline Color of kernels. . & 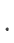 & . & . & ז & & \\
\hline Market comelition & & . & . & 10 & & \\
\hline 'Tips of ears . . . & & . & . & $\pi$ & & \\
\hline Butts of ears. . . & & . & . & $\therefore$ & & \\
\hline Lniformity of kernel & & . & . & 10 & & \\
\hline Shape of kernels. . & & . & . & 10 & & \\
\hline Space between kermel: & & . & . & ז & & \\
\hline Weight of grain. & $\cdot$ & . & . & 2.5 & & \\
\hline
\end{tabular}

Student's Name

Dite

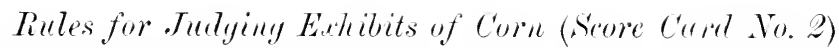

Uniformity of Exhibit. The ears in an exhibit should he similar in size, shape, color, and indentation. For each ear deficient in these respects eut the exhilit one point. 
Shupe of Ears. The ears should be cylindrical, or nearly so. Cut the exhibit one print for each ear deviating from this resuirement.

Color of coll. The cobs shoukl be uniformly red or uniformly white. For each white coh in an exhibit in which the red predominate, cut the exhibit one-half point. Do the same for each red coll in an exhilit of white cobs.

Color of hernels. For each white-crowned kernel in a yellow or red variety cut the exhibit one-tenth point. For each yellow kernel in a white variety give the same cut.

Hurlet condition. The corn should be well matured, firm, and sound. For each ear deficient in these respects cut the exhilit one print.

Tipss of Eurs. The tips of the ears should be covered with regular, uniform kernels. Aild together the lengths of protruding cobs on all ears of the exhilit, and cut at the rate of one-half point for each inch.

Butts of Eurs. The rows of kernels should be even and swell out evenly beyond the end of the col. C'ut the exhibit one-half point for each poorly filled hutt, and one-fourth point for each flat butt.

Uniformity of Kernels. The kernels should possess similar characters. C'ut the exhilit one-half point for each deficient ear.

Shape of Keruels. The kemels should have a wedge shape on the broad side, and on the narmo side the edges should be parallel. Cut one wrint each for each oljectionable ear.

Sipere between kimels. The rows of kernels should not be more than one thirty-second of an inch apart at any part of the row. If more than one sixteenth of an inch apart, cut 
one-half point; if less than that, but more than one thirtysecond, eut one-fourth point for each ear.

Weight of Grain. The weight of grain on an arerage ear should come up to the following requirements:

Length of ear 12 inches and over, weight of grain 17 ounces.

Length of ear 11 to 12 inches, weight of grain 15 ounces.

Length of ear 10 to 11 inches, weight of grain 14 ounces.

Length of ear 9 to 10 inches, weight of grain 13 ounces.

Length of ear 8 to 9 inches, weight of grain 11.5 ounces.

Length of ear 7 to 8 inches, weight of grain 9.5 ounces.

Length of ear 6 to 7 inches, weight of grain 8 ounces.

For each omnce helow the number recpuired by an ear of given length cut the exhibit two points.

\section{Testine: Con for Vinbilite}

Standard for germination, 95-98 per cent.

The importance of making germination tests of corn cannot he emphasized ton strongly, since seed corn will often have a fair outward appearance and yet germinate poorly.

When the germinating power of corn is very low, and reliable seed is hard to pick out, it is often desirable to make germination tests of each ear separately.

To do this, first number the ears ly slipping a piece of cardboard containing the number between two rows. Remove two kernels from the butt, two from the middle, and two from the tip of each ear. Then, taking the germinator described on page 94 , mark off the blotting paper in the bottom into two-inch squares, numbering each. Now put the grains from each ear in their respective squares, and allow to germinate. 
In this way several hundred ears may be tested at once.

For testing a large lot of corn in the ear select 100 ears at random and take six kernels from each ear, as described above. Corn seems to germinate more poorly near the butt than at any other point. Place seed in germinator. Germination should begin in about two days and should be complete in six.

For best results keep temperature as near $80^{\circ}$ to $90^{\circ} \mathrm{F}$. as possible, and never let fall below $60^{\circ} \mathrm{F}$.

\section{Commerchal (iramingr of Corn}

The grades of corn are usually designated as "White Corn," "Yellow Corn," or in case of a mixture of the two (amounting to more than 25 per cent) it is simply called "Corn."

Usually three grades of white and yellow corn are made and four grades of the mixed corn. In examining and grading corn the student should take into consideration the following points.

\section{Sotes on the Qundity of Corre}

Color. No. 1 Corn should be true to color, hut in grades 2 and 3 considerable mixture is allowed, varying from 10 to. 25 per cent.

Soundness. Good com should not only be thoroughly cleaned up, but should also be reasonably free from decayed or cracked kernels. Cracked kernels often indicate that the corn was damp' when shelled. Any considerable per cent of chaffy or shrunken kermels injures both the feeding and milling value of the corn.

Moisture. Corn in a wet or heated condition cannot be graded. 
Go over each sample carefully and make out a short rejort on each, giving first the commercial grade, and then the amount of mixture, if mixed, also the kind and nature of any impurities or injury the grain may have suffered from exposure, sprouting, or heating in crib or hin. The following form of report is suggested:

\begin{tabular}{l|c|c}
\hline \hline SAMPLE NO. & GRAIE & REMLRKS \\
\hline & & \\
\hline & & \\
\hline
\end{tabular}

For this work from 20 to 25 samples of corn are provided. These should include samples of pure yellow and white corn of the various grades, in various stages of cleanliness, dampness, etc. Also samples of mixed corn, starting in with pure white and yellow and mixing them in various proportions.

\section{Corn-Inspection Rinles 1}

No. 1 Yellow Corn shall be yellow, sound, dry, plump, and well cleaned.

No. 2 Yellow Corn shall be three fourths yellow, dry, reasonably clean, hut not plump enough for No. 1.

No. 3 Yellow Corn shall be three fourths yellow, reasonably dry, and reasonably clean, but not sufticiently sound for No. 2 .

No. 1 White Corn shall be sound, dry, plump, and well cleaned.

${ }^{1}$ Rules adopted by the Board of Railroad and Warehouse Commissioners for the inspection of grain at Chicago. 
No. 2 White Corn shall be seven eighths white, dry, reasonably clean, but not plump enough for No. 1.

No. 3 White Corn shall be seren eighths white, reasonably dry, and reasonably clean, but not sufticiently sound for No. 2.

No. 1 Corn shall be mixed corn of choice quality, sound, dry, and well cleaned.

No. 2 Corn shall be mixed corn, dry and reasonably clean, but not good enough for No. 1 .

No. 3 Corn shall be mixed corn, reasonahly dry and reasonably clean, but not sufficiently sound for No. 2.

No. 4 Corn. Corn that is badly damaged, damp, or very dirty, shall be graded no higher than No. 4 .

Corn that is wet or in heated condition shall not be graded. 


\section{SECTION III - OATS \\ CLASEIFICATION OF SPECIES}

Order

Graminere

(ienus derme

sirecies

stativa

The cultivated varieties are sometimes classified according to the form of the panicle, and are considered by some botanists as distinct species. The "common vat" (A cena sativa) comprises those rarieties having spreading panicles, and the "Tartarian oat" (Atenc oricntulis) comprises varieties with close, erect panicles, commonly called "side oats," while the other is called "branch oats."

There is also a type (Avenu rudu) from which the hull is remored in threshing. Varieties of this are found in both of the ahove groups.

The hulled varieties are also divided, according to the color of the hull, into white, gray, red, and black oats.

The oat differs from the other cereals in having its heads in the form of panicles instead of spikes, and the grain is not attached directly to the main stem of the plant.

In form of grain and height of straw varieties differ considerably.

A good oat grain should he fairly plump, have a thin hull, and weigh from 32 to 38 pounds per measured bushel.

The stalk should be of medium height and sufficiently strong and stiff to stand erect. 
Is in the case of most other cereals, the varieties of oats are very numerous and adapted to different conditions.

In regard to yield and quality there seems to be in general no particular difference between oats of different color or

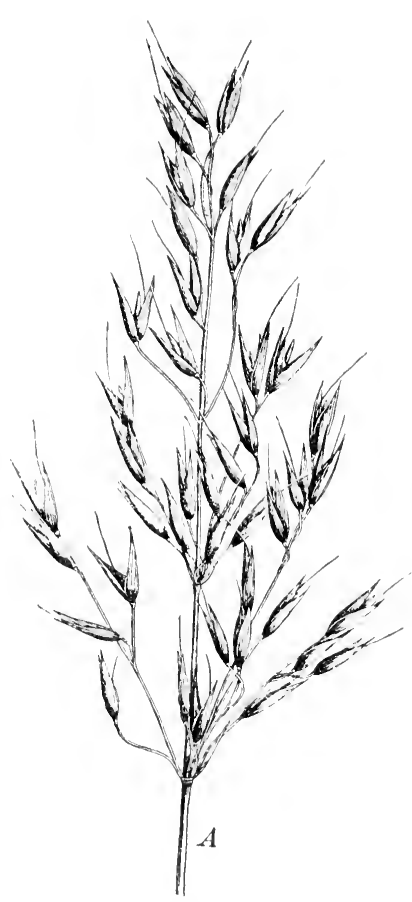
vats with open or closed panicles. The differences seem to loe due solely to variety characteristics and conditir. affecting grow

The shape the grain ve ss comsiderably in different varieties, some heing very long and rather slencler, while other's are of a short and thicker type.

In the southern regions the proportion of Fri. 17. Types of oat hearls: A, panieled mats; $B$, sirle oats hull to herry tends to increase.

Remove hulls of several varieties and get proportion hy weighing. (Hulls are more easily remored if soaked in a dilute solution of watassium hydrate or :3:? per cent alcohol for a few m: 
The feeding value is decreased by a large proportion of hull. The froprortion of hull varies with its thickness and with the size of the herry.

\section{LABORITORY STIOY OF CIIARACTERS}

Examine in head samples of common varieties of side and paniclerl vats.

I law a hranch and two or three spikelets.

I issect out carefully a spikelet and draw its parts in their relative position.

Now examine each hear carefully and note down its characteristice in the "Outline for describing Oats," using the list of descriptive terms as a guicle.

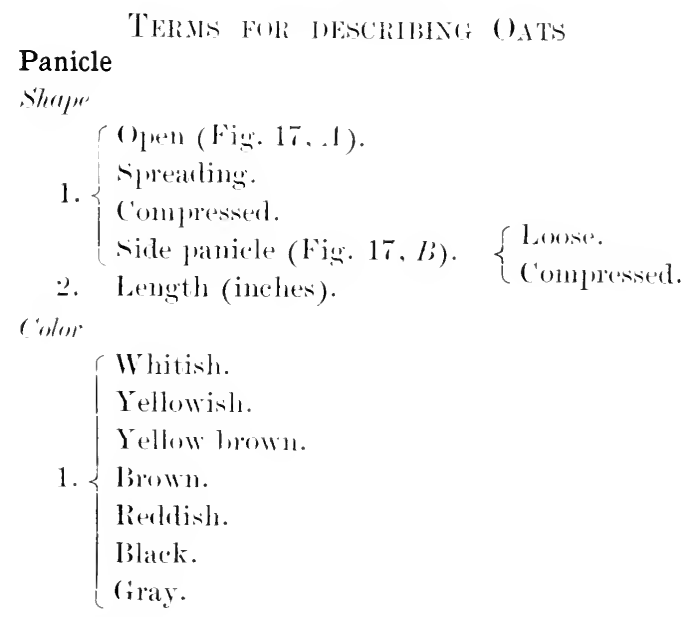

\section{Spikelet}

1. $\left\{\begin{array}{l}\text { Npreating. } \\ \text { Narrow. }\end{array}\right.$

2. Number of grains, 1, 2. 3. 


\section{Grain}

sterye

( Lomg (Fin. 1s. 1).

1. Mediuntu.

Short (Fig. 1s. l').

cylindrical.

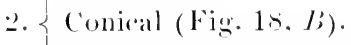

Medge-shaped (lig. 1n, l).

cierese

1. $\left\{\begin{array}{l}\text { Full. } \\ \text { l)eele. }\end{array}\right.$

Weight of 100 gatins.

Tij,

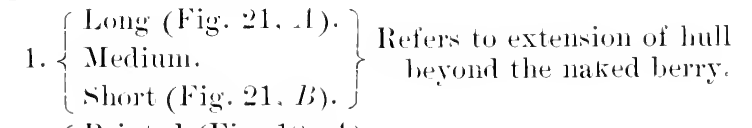

2. $\left\{\begin{array}{l}\text { Pointed (Fig. 1s. I). } \\ \text { B] lunt (Fig. 1s, l'). }\end{array}\right.$

IIull

1. I'Prent.

$(\mathrm{inl}))^{\circ}$

1. $\left\{\begin{array}{l}\text { Whitish. } \\ \text { Yellowish. } \\ \text { Brownish. } \\ \text { Rerdisll. } \\ \text { Black. }\end{array}\right.$

Dorsal awns

1. $\left\{\begin{array}{l}\text { Dongs. } \\ \text { Medium. } \\ \text { Nhort. } \\ \text { None. }\end{array}\right.$
1. $\left\{\begin{array}{l}\text { Whitish. } \\ \text { Brownish. } \\ \text { Sellowish. } \\ \text { Blatrk. } \\ \text { Brown or hlack at hase and lighter at tip. }\end{array}\right.$ 

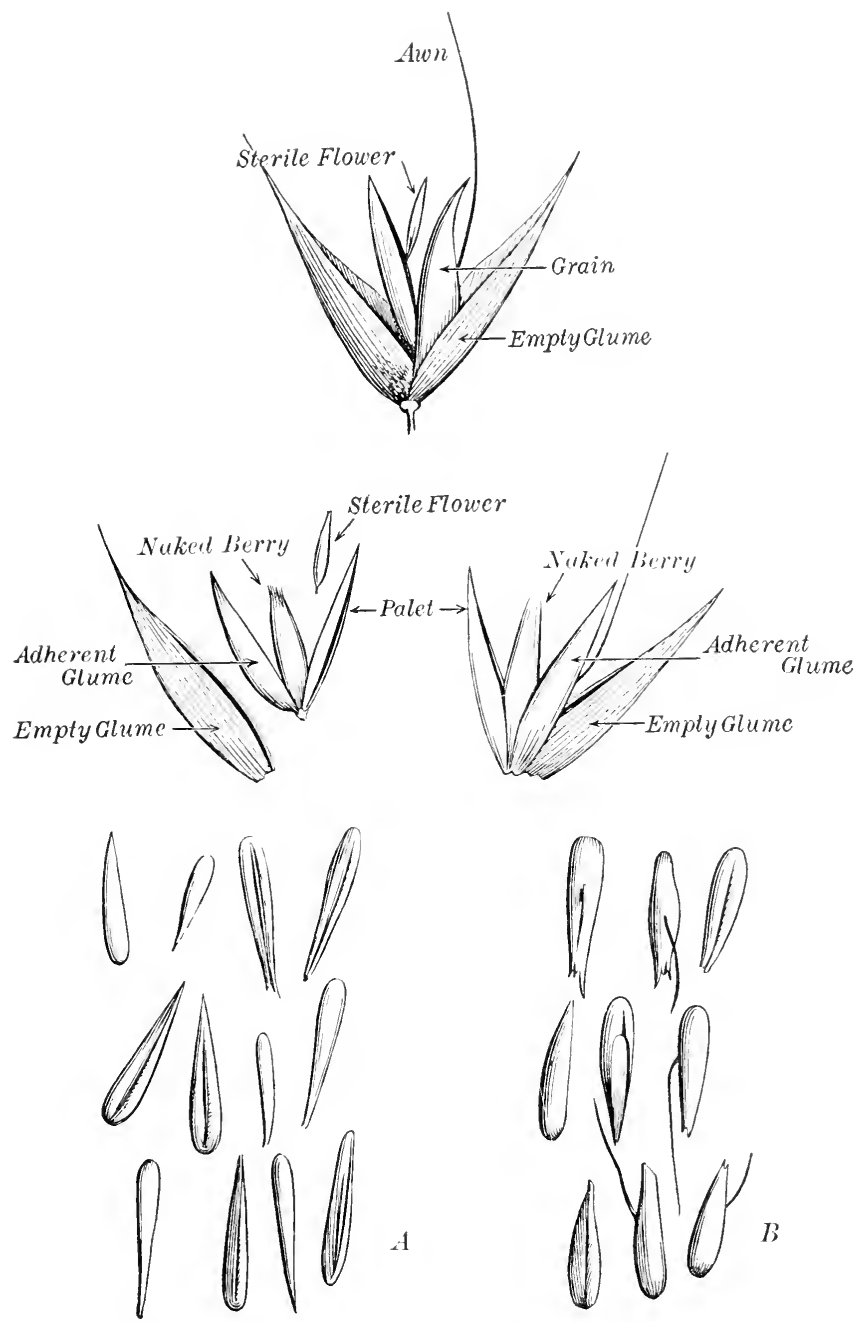

Fig. 18. Oat spikelets and grains. The upper figures show an entire oat spikelet, both in its natural form and when torn apart, with all parts named. The lower figures show two types of oat grains: A, long, pointed; B. short, blunt 
Use the following outline in describing oats in head. Write in the blank space under the number of the oat being described, and opposite the proper heading, the term which applies, using the list of "Terms for describing Cats" as a guide.

\section{Panicle}

\section{()TLLAE FOR IDESCRIBINE OATS}

Shlupe

1
2
Costor
1

\section{Spikelet}

1 .

2

\section{Grain}

Shape

1
2
Creeres
1

Weiglte of 100 grains (srams) ...

Tii)

IIull

Costeri

1

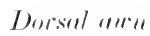

1

rislor

1.

2

Nimlent $x$ Name.

1)ate 


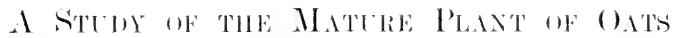

(Prepared hy A. T. Wiancko, Purlue Tniversity)

I'se the material povided by the instruetor, and describe aceording to the following outline:

1. Length of panicles in intehes (arerage of five lanicles from base of lower whorl to tip of flowering ghume of npler spikelet)

2. Number of whorls (average of five panicles)

3. Number of main hanches (average of five panicles)

4. Variation in length of peelicel of spikelet to to

5. Number of gratins per spikelet

6. Relative weight of lower and ulper grams of spikelet: weight of 2.5 lower grains

; weight of 25 uplere grains.

7. Nmuler of grains (arerage of five panicles)

s. Weight of grains (average of five pranicles).

$$
\text { weight of } 100 \text { grains }
$$

9. Per cent of kermel: weight of 100 grains weight of 100 keroluels. ; rex cent

10. Plumpluess: plumpl, medinn, intlaterl.

11. Color of grain: light yellow, yellow, gray, reetdish brown, black.

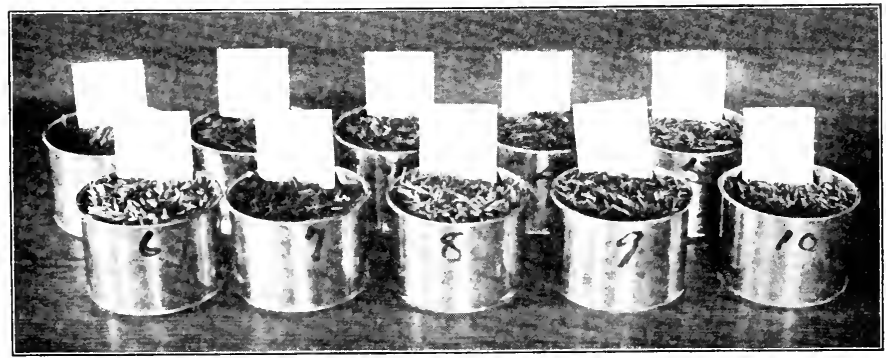

Fig. 19. A set of ten samples of oats ready for study. The cups hold one pint each 


\section{EXIMINING THE QUALITY OF OATS}

For this exercise ten or twelve samples in cups are providerl, as in the work with wheats. These samples should include

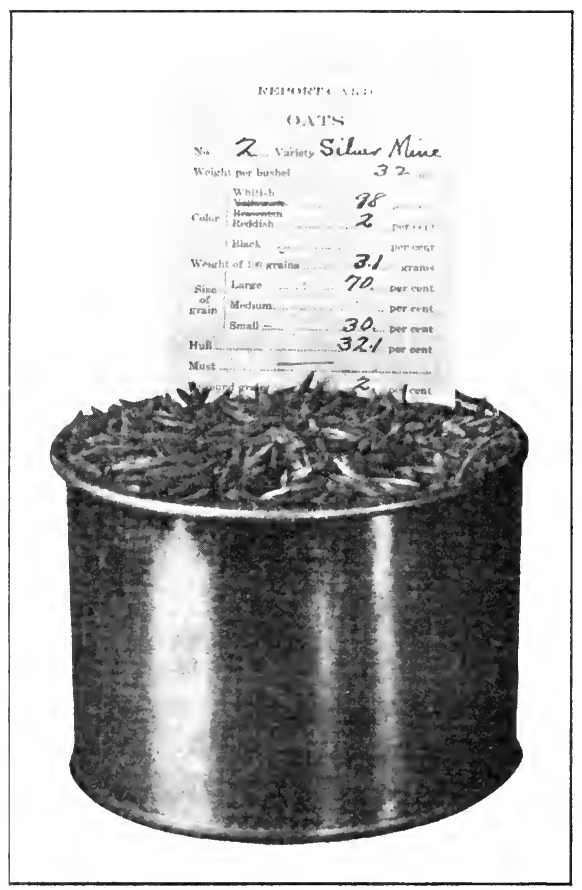

Fig. 20. A tin pint cup filled with oats, and the report card made out at least one sample of each of the principal types, and should exhilit as wide a range of qualities as possible. First fill out a card for each sample, similar to Form No. 2 , giving an analysis of each. The meanings of all the terms are apluarent enough not to require explanation unless it he " la roge," "medium," and "small," under "Size of Grain." 1 This data is only intended to give some idea of the uniformity in size of grains in the particular sample under consideration, and not the relative size when all varieties are considered.

After a card has been made out for each sample, arrange the samples according to weight per bushel. Explain in writing 1 'The term "grain" is nser to designate the hull and the berry it contains. 
the various causes to which the light weights of the tive lighter samples are aplarently due.

Make out a written statement showing which is the best rat, (") from the feerler's standpoint; (b) from the seedsman's standpoint; (c) from the miller's standpoint.

\section{Lirin)tet ('ir)}

( ) MTis

No.

Weight fer hoshel

Variety

Color $\left\{\begin{array}{l}\text { Whitish.. } \\ \text { Yellowish } \\ \text { Browmish } \\ \text { lieddish. } \\ \text { Black. }\end{array}\right.$

size Latrge.

of $\{$ Medimm

grain Sinall

Weight of 100 gatains

II 1111

Must.

Lnsoumd grain

Foreign matter

Viability
$11 \mathrm{~s}$.

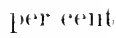
per eent per cent jer cent per cent per exent perent pere and c..s?allm, pere cent ler centit per eent per cent

[FoRM No. 2]

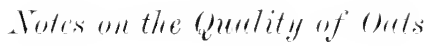

Mustiness. ()ats should the free from must, as it injures the palatability and feeding value of the grain; it also gives horses a cough.

Purity. Oats should be fairly clean, but more foreign matter is allowed in oats than in corresponding grades of other grain. 
An occasional kernel of corn or wheat is not so ohjeetionable in a grain userl largely for feerling purposes as in a grain for milling. Iteed stems and seeds are not only worthless
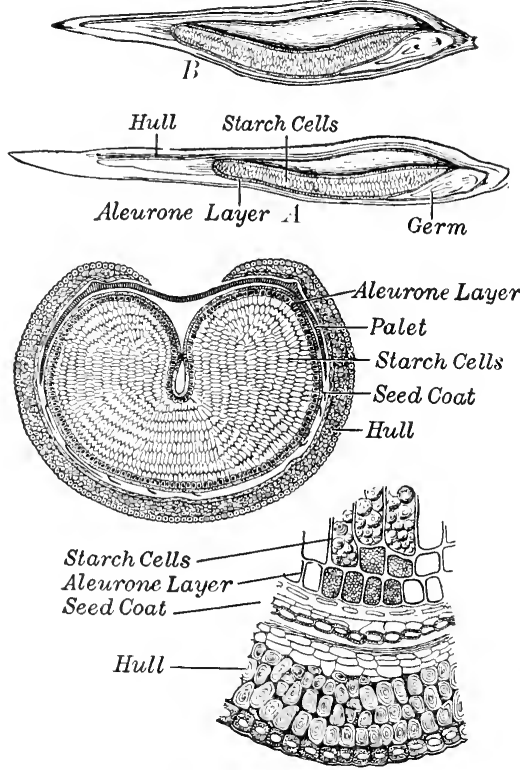

Fici, 21. Sitructure of the oat grain. The uper figures illustrate a short thick and long slenter type of oat grain. They are figures are transverse sections, drawn to) sicale ent through at the crease. The lower

hut may give a bad taste to the grain.

I'lumpuss. Other things heing equal, a plump grain is always preferrerl, since it usually has a less proportion of hull and consequently higher feeding value.

Sonndness. Decayed and weather-beaten grain not only suffers in appearance, but the feeding yuality is injureel, since only a small amount is sufficient to injure that sweet, palatable flavor which bright, clean oats should have.

Wright. When different varieties of oats are being compared the weight per bushel is not always a fair inclication of their relative value. Some varieties of oats have an awn on the hack of each grain, which prevents the grains from settling together closely in the measure and giving a high weight per bushel, although the individual grams may he of the best quality. Other varieties 
have a long projection of the hull over the berry, or a rough hull, and for these reasons it may often happen that a smoothgrained, awnless variety will weigh more per bushel than a rough-hulled, awned variety of oats, although the individual grains are not as phump or well teveloped. Even in the same variety the different conditions under which the oats may he cut and threshed will affect the weight jer hushel. However, in oat varieties of similar tharacter the weight per bushel may be taken as a fair indication of feeting value, the lighter 'oats having a larger proportion of hull to berry than the heavier.

\section{JUDGING OATS}

First score the ten samples used in the last exercise, making use of the same data. The student should then have access to a general collection of oat samples. It is much better if these can he supplied in peck or half-bushel lots.

\section{Sicoie Creid for Oats}

Variety Name

Sample Number.

Uniformity, $20 \%$

(a) In color.

(b) In size

Quality, $80 \%$

(a) Weight per bushel

(b) Soundness and dirt

Crentr

(c) Per cent of hull

11
11

(d) Size of grain

(e) Must, smut

Total

100

Student's Name

Date 


\section{Explanation of Seore Card}

In this score card oats are judged entirely from the feeder's standpoint. It is not possible to make a score card by which an oat could he judged at the same time from both the feeder's and the miller's standpoint, and also judge the grain for seed. Different points would be used in each ease, and different values given them.

Uniformity in Color. Iniformity in color and size are of only minor importance to the feeder. IDivide the sample aceorling to the eolor of the grains. Let the elass having the largest number determine the color. Chut one point for each two per cent of other colors.

Iniformity in size. Divide the sample into two parts aceording to size of grain. Estimate per cent of small grains by count. Cut one print for each four per cent of small grains.

Itright per Busher. The weight per hushel is a very important consideration in estimating the value of an oat for feeding purposes. A heary weight indicates that the grain was well matured and filled out. In the same variety a heary oat usually has a less per cent of hull, and consequently a higher feeding value than a light oat. The best oats should weigh 38 pounds per hushel. ('ut one point for every pound light down to 32 pounds per hushel, and two points for every pound light below this.

Soumlness and Dirt. Sprouted or decayed grains have little more value than so much trash, and may he regarded as such for julging purposes. Sieparate all unsound grains and dirt, estimate the per cent hy weight, and cut two points for each one per cent. This cut is not limited to ten points, but may be indefinite. 
Per Cent of Hull. The percentage of hull varies with varieties, the locality in which the oat is grown, and also depends on how well and perfectly the grain was matured. In growth the hull and bran develop first, and the starch is deposited last. However, if from any cause such as dry weather, poor soil, injury from insects, etc., the grain is prevented from maturing perfectly, the development of the starch is somewhat curtailed, and consequently the percentage of hull is higher. A good oat may have as high as 30 per cent hull. Cut two points for every per cent of hull above this.

Size of Groin. Size varies greatly with varieties, but 100 grains should weigh 3 grams in heary oats. Cut one point for every two tenths of a gram less.

Must and smut. If must or smut is very apparent, the sample should he eut 10 peints.

\section{Commerchat Grathes of Oats}

The work in commercial grading is carried ont by first examining a set of samples representing the commercial grades.

Then as large a set of miscellaneous samples as possible should be examined and graded according to ofticial inspection rules. The samples previously examined in studying oats should be graded, as the sturlent already has a good knowledge of the comparative value of these.

\section{Oat Inspection Rules 1}

No. 1 White Oats shall he white, sound, clean, and reasonably free from other grain; weight 32 pouncls.

${ }^{1}$ Rules adopted by the Board of Railroad and Warehonse ('ommissioners for the inspection of grain at ('hicago. 
No. 2 White (lats shall be seven eighths white, sweet, reasonably clean, and reasonably free from other grain ; weight 28 pounds or above.

No. 3 White Gats shall be seren ëghths white, but not sufficiently sound and clean for No. 2.; weight 2.2 pounds or better.

No. 4 White ( )ats shall be seven eighths white, damp, badly damaged, musty, or for any other cause unfit for No. 3.

No. 1 White Clipped Oats shall be white, somd, clean, reasonably free from other grain, and shall weigh not less than 36 pounds to the measured hushel.

No. - White Clipled (hats shall he seven eighths white, sweet, reasomally clean, reasonably free from other grain, and shall weigh not less than 34 pommls to the measured bushel.

No. 3 White Clipper Oats shall he seven eighths white, not sufficiently sound or dean for No. 2, and shall weigh not less than 28 pounds to the measmed bushel.

No. 1 (Gats shall be mixed bats, somnd, clean, and reasonably free from other grain.

No. 2 Oats shall be sweet, reasonalily clean, and reasonahly free from other grain.

No. 2 Cats shall be mixed oats, not sufficiently sound and clean for No. 2.

No. 4 (Gats shall be all mixed oats that are damp, badly damaged, mustr. or for any other cause unfit for No. 3.

In examining and grading the samples of oats take up each point separately, as in wheat, making notes of your observations and reporting on each after the manner of the table on the following lage. 


\begin{tabular}{|c|c|c|}
\hline $\begin{array}{c}\text { NUMBER OF } \\
\text { SAMPLE }\end{array}$ & (IRALE & REMARK \\
\hline 1 & No. 2 Oats & $\begin{array}{l}\text { Weight } 30 \text { lb. per bushel; grains plume; } \\
\text { slight mixture of barley; sweet and } \\
\text { bright. }\end{array}$ \\
\hline
\end{tabular}

\section{Testixi: UAts foR l'URIT}

Standard for purity 99 per cent.

Thoroughly mix the oats to be tested and take out about a half-pint sample. Spread this on a table and carefully separate out the impurities. Then find hy weight the amount of pure seed, as well as the foreign matter, and from this calculate the per cent of purity.

An oat sample may sometimes contain as much as 5 per cent foreign matter and still pass the casual observer as a fairly clean sample.

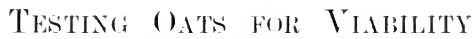

Standard germination 95 per cent.

If taking a sample for germination from a lin, do not take it from one place, but mix up thoroughly several scoopfuls taken from different parts of the bin, and then from this take a small sample and pick out at random 100 grains. Place these in a germinating apparatus as described on page 94 .

Moisten daily and keep at a temperature of $80^{\circ}$ to $90^{\circ} \mathrm{F}$. (remination should hegin in three days. $A$ s soon as the radicle is one fourth inch long the grain has germinated.

Remove all sprouted grains daily until germination ceases. Then by counting the number which failed to sprout, and subtracting this from 100, you have the per cent of germination. 


\section{HOT-WATER TREATMENT FOR EITIIER LOOSE OR COVERED SMLT IN OATS'}

(Prepared by A. N. Hume, University of Illinois)

Place a sufficient amount of seed oats in a bag or basket which will readily admit water, and immerse for ten minutes in hot water at $133^{\circ} \mathrm{F}$; then cool quickly by immersing in cold water or by stirring thoroughly while drying.

Having treated the seed oats as above, make a duplicate germination test of the treated seed, and also a duplicate germination test of untreated seed to serve as a check.

Report as follows:

\section{Trented sied}

Per cent of germination : (1) ; $\mathrm{Ar}$.

Eutreated sierd

Per cent of germination: (1) ; $\Lambda \mathrm{r}$. Does the hot-water treatment injure the vitality of the seed? student's Name late

FORMALIN TREATMENT FOR EITIER LOOSE OR COVEREI SULT IN OATS'

(Prepared by A. N. Hume, University of Illinois)

Treat seed by sprinkling or immersion for 30 minntes with a solution of 1 pound of formalin (40 per cent solution of formaldehyde) to 50 gallons of water.

In all treatments it is well to first stir the seed into a tub of cold water and skim off the smut balls which rise to the surface. After treatment the drying may be hastened by using slaked lime.

1 This treatment can also be used for stinking smut in wheat. 
Having treated a sufticient quantity of seed oats as above, make a duplicate germination test of the treated seed, and also a duplicate germination test of untreated seed to serve as a check.

Report results as follows:

Treater sied

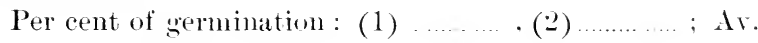

Untreated Seed

Per cent of germination: (1) ….... (22) …........ Ar.

loes the formalin treatument injure the vitality of the seed?

Student sime

Dite 


\section{SECTION IV - BARLEY}

\section{(LASSIFICATION OF SPECIES ANI) VARIETIES}

Order
Gemus
Species

Cultivated harleys include a number of types, or races, which by some are considered as subspecies and classified as follows :

(1) Two-rowed harley Horderm satirum distichon

(2) six-rowed barley Hordenm sativem hexastichon

The two-rowed barleys commonly grown are characterized by their large, plump grain. In Europe these barleys are used almost exclusively for malting, and hence the name "malting barleys" has come to be generally applied to them. However, in America the six-rowed barleys are generally used for this purpose.

The six-rowed harleys include the "naked," or " hull-less" varieties, as well as most of our common cultivated harleys. The six-rowerl barleys are generally more prolific than the two-rowed, and are most generally grown in this country. The grains of six-rowed barleys are smaller and not so plump as those of the two-rowed barleys, but are higher in nitrogen.

The varieties of harley are numerous, but only a comparatively few are grown in the Inited States. 
Carefully examine samples of each of the above types of harley, inclurling samples of both black and white hulless barley.
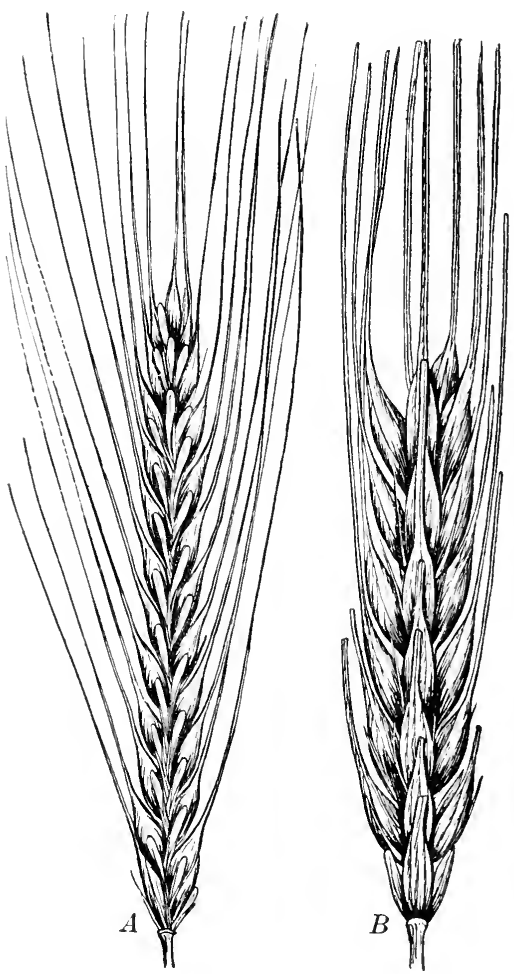

Fic. 22. Types of barley spikes: $A$, two-rowed brewing barley; $B$, sixrowed hulless barley

Make drawings from a spike of each type, showing the imbricated view.

Note that the berry of ordinary barley is tightly inclosed by the flowering glume, called the "hull," while in hulless 
barleys the flowering glume and palet do not adhere closely and the berry is free.

In this respect hulled harley is similar to oats, and hulless to wheat.

\section{LABORATORY STELY OF C'HARACTERS}

Typical samples in the spike and of the threshed grain are provided. Carefully describe both the spike and grain of one or more samples of the principal types of barley, as the two-, four-, and six-rowed barleys, and black and white hulless harleys.

The characteristics are ohvious enough, so that with a little careful comparison there should be no trouble in finding the proper adjective in the descriptive list.

Cse the outline for describing barleys, filling it out carefully.

\section{Spike}

\section{TERMS FOR DESCRIBIN; BARLEYS}

1. $\{$ 'Two-rowed (Fig. 22. A). ? This refers to the number of rows $\{$ six-rowed (Fig. 2.2, B). $\}$ of grain on the spike.

2. $\left\{\begin{array}{l}\text { Awned (Fig. 2.2, 1). } \\ \text { Partly awned (Fig. 2.2. l') } \\ \text { Awnless. }\end{array}\right.$

3. Length (inches).

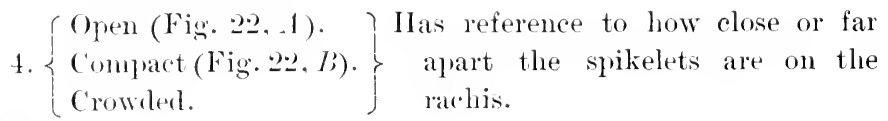
shape

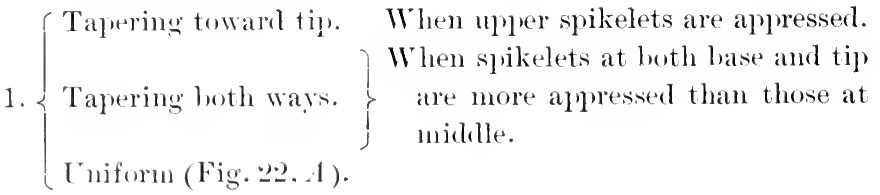




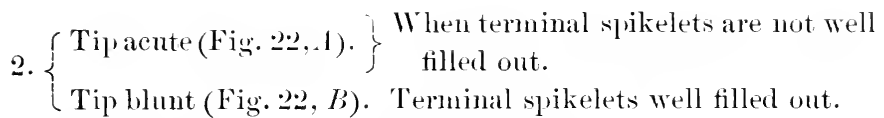
$3 . \begin{cases}\text { Base aljupt. } & \text { Basal spikelets well filled out. } \\ \text { Base tapering. } & \text { Basal spikelets not well filled ont. }\end{cases}$

4. Sterile spikelets, $1, \cdot 2$, :3, etc.

Color

$$
\text { 1. }\left\{\begin{array}{l}
\text { Whitish. } \\
\text { Yellowish. } \\
\text { Yellowish brown. } \\
\text { Brown. } \\
\text { Black. }
\end{array}\right.
$$

\section{Awns}

1. $\left\{\begin{array}{l}\text { Long (length } 5 \text { inches or more). } \\ \text { Mediun (length } 3 \text { to } 5 \text { inches). }\end{array}\right.$

Short (length less than :3 inches).

2. $\left\{\begin{array}{l}\text { Parallel (Fig. } 2, B) . \\ \text { spreading }(\text { Fig. } 2.2,1) .\end{array}\right\} \begin{aligned} & \text { Refers to the relative position } \\ & \text { of the awns to the head. }\end{aligned}$

3. $\left\{\begin{array}{l}\text { Deciduous. } \\ \text { Partly deciduous(Fig. 2.2, IS). } \\ \text { Persistent (Fig. ‥2.2, 1). }\end{array}\right\}$

This refers to the droplping of the awns at maturity. The awns all drop off on some varieties, while on others they are very persistent.

Color
1. $\left\{\begin{array}{l}\text { Whitish. } \\ \text { Yellowish. } \\ \text { Brownish. } \\ \text { Black. }\end{array}\right.$

\section{Spikelet}

(This is not a spikelet in the botanical sense, but really a mesh of three spikelets.)

1. Number grains per spikelet $(1,2,3)$.

2. Number of sterile flowers. (Refers to sterile flowers in a spikelet.) 
Size

Broarl (Fig. 28, C).

1. \{ Medimu (2:3. l;).

(Narrow (Fin. 2:?. A).
This depends largely on the shape of the grain and how well it is developert.

cher Cilume. (In harleys these are very narow and pointed.)

S Awned (Fig. 2:3. P).

1. $\{$ Awn-pointed. Awnlesin (Fig. 28. I). J ing or seed-bearing glume.

The outer or empty glume should not he confused with the flower-

\section{Grain}

Snclosed in flower-

This is the distinguishing characteristic 1. $\{$ ing glome.

Fire (naked).

between the naked or hulless barley and the ordinary kind. In the latter the grain is so tightly inclosed that it is not freed in threshing.

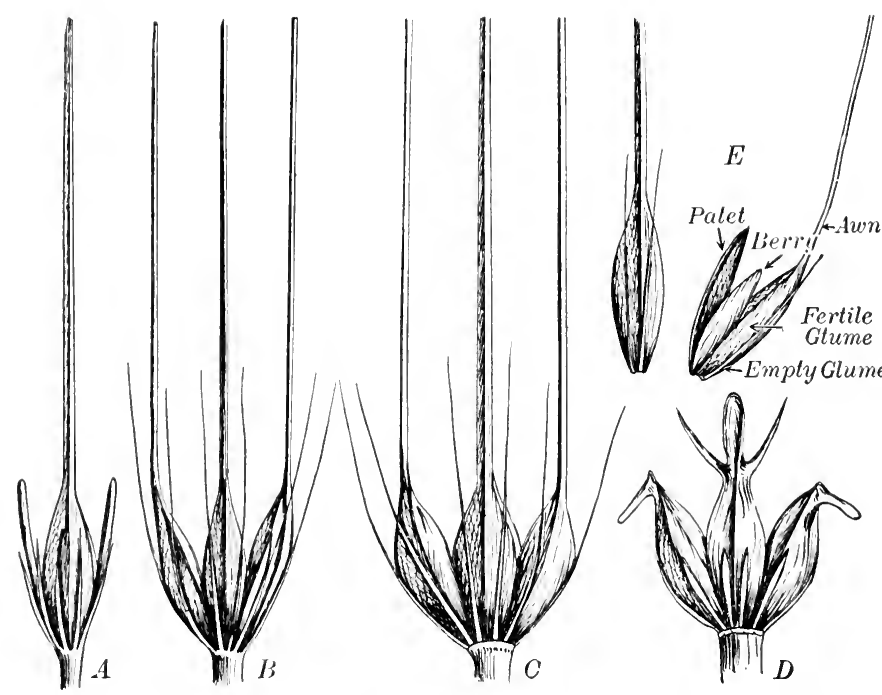

Fur. 23. Types of barley spikelets: $A$, spikelet from two-rowed barley; $B$, spikelet from six-rowed barley; $C$, a six-rowed hulless barley; $D$, a white hulless and awnless barley; $E$ shows a barley spikelet torn apart 


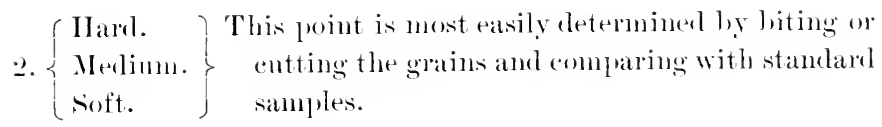

shatere

1. $\left\{\begin{array}{l}\text { Loms. } \\ \text { Merlium. } \\ \text { Sloort. }\end{array}\right\}$

Different varieties of harley show considerable variation in size and ration length to dianeter. Pick out about six typical grains to examine for these points.

2. $\left\{\begin{array}{l}\text { Thin. } \\ \text { Metlimm. } \\ \text { Pluml. }\end{array}\right.$

Crertise

1. $\left\{\begin{array}{l}\text { Inell. } \\ \text { Medimuln. } \\ \text { Full. }\end{array}\right\}$

Cut cross sections of several typical grains.

('ioss sertiont

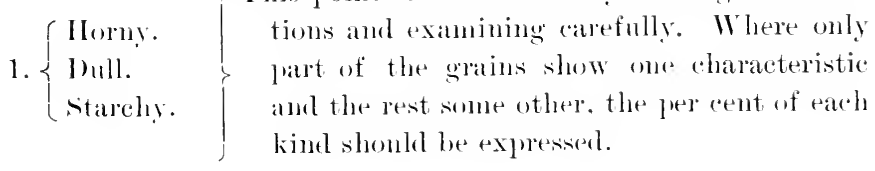

Color

$1\left\{\begin{array}{l}\text { Black. } \\ \text { Purple. } \\ \text { Purplish. } \\ \text { Brown. } \\ \text { Yellowish. } \\ \text { Whitish. }\end{array}\right\} \begin{gathered}\text { When black hulless barleys are fully matured } \\ \text { they are gurplish black in color, hut when the }\end{gathered}$

Wright of 1011 ! grains grants 
Spike

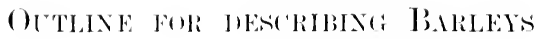

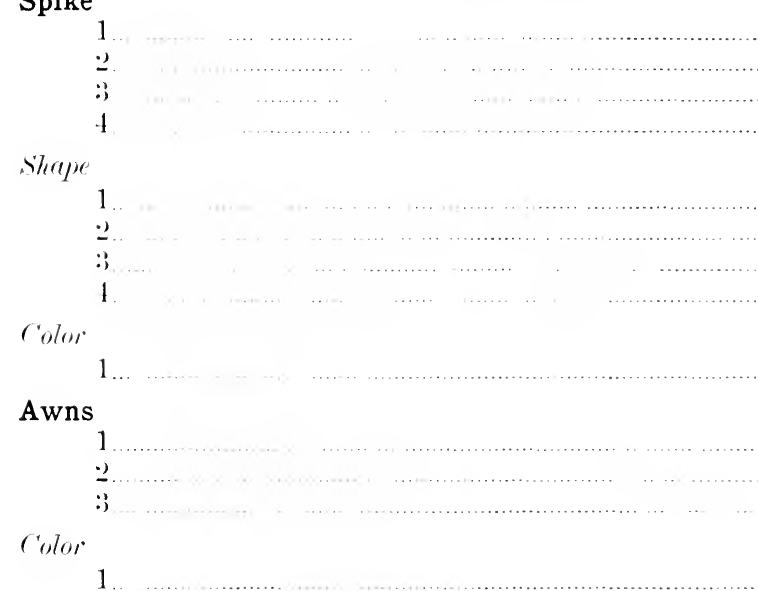

\section{Spikelet}

1
2

size

1.

Cleter (ilume

1

Grain

\section{1}

sthorpe

1

Crectse

1

Cross sertion

1

Color

1

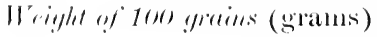




\section{Examing the Quality of Barley}

For this exercise some ten samples of barley are provided in cups. The widest possible range of type and quality should be included. First fill out a report card for barley, Form No. 3, for each sample. The card gives an analysis of the sample. By using the score card the value of the sample from a brewer's standpoint may be obtained.

\section{Report Card \\ BakLey \\ Variety}

No.

Weight per bushel.

11.

S Good color:

.. 1er cent

Color \{ Somewhat discolored _.......................................... per cent

Badly discolored ................................................... per cent

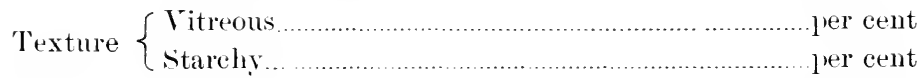

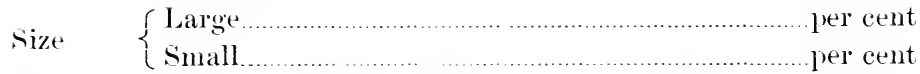

Berries exposed or cracked through injury in threshing........ per cent Sprouted (number) …………………………………............ per eent

Bin burnt, decayed, ete. …………………………………..... per cent

Weight of 100 grains _............................................................. grams

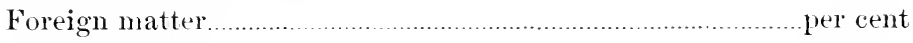

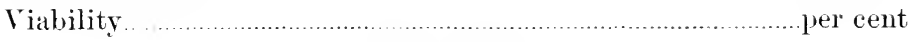

[Forim No. : $]$

Using Report Card for Burley. The weight per bushel will have to be obtained from a large sample by the ordinary method (see pp. 98, 99). For obtaining the rest of the data see the "Explanation of the Score Card." The viability can only be obtained by testing the sample in a germinator. 
In jurlging harley from the lorewer's standpoint only good unlleached samples can be used, while from a feeder's standfoint a slight discoloration would be no oljection.

The price of white barley is gorerned by the lrewing qualities of the grain. Any discoloring or bleaching disqualities it for this purpose.

A few proints to be observed in grading harleys are as follows:

\section{Sotes on the Queclity of Burley}

Color. White barleys should be a clear, light color, with no tint of yellow or brown.

Bleaching and discoloring caused from exposure to the weather is probably the most common cause of injury to white barleys. Bleaching not only disqualifies barley for malting purposes by injuring the color of the product, but the wetting and drying which the grain is subjected to when bleached injures its malting properties.

Black barleys when fully matured are usually a blue black, but if harvested lefore fully matured, many of the grains will be brownish, with varying degrees of purple or blue, shading to almost black.

Truture. The texture of barleys varies from quite hard and horny (vitreous in appearance) to a crumbly texture, white and very starchy.

A good way to examine both the texture and hardness of a barley at the same time is to bite several grains in two. The difference in hardness and texture is directly correlated with the variation in protein content. The rery soft and starchy barleys contain the least proteids, about 8 or 10 per 
cent, while barleys with a hard, horny texture, and usually vitreous appearance, sometimes contain as high as 15 per cent proteids.

Size and Height of 100 Grains. The grains of two-rowed barleys are larger than the grains of six-rowed barleys. Large-grained barleys, even of the same type, seem to be generally more starchy and contain less protein than the smaller-sized grains. It is for this reasom that the German hrewers select the large-grained, two-rowed barleys, and American brewers the smaller-grained, six-rowed barleys.

Brewing Qualities. (xerman brewers generally prefer harleys of very low proteid content, — from 7 to 9 per cent. Howerer, American hrewers are using with good success many western and northern barleys containing as high as 12 to $1+$ per cent proteids.

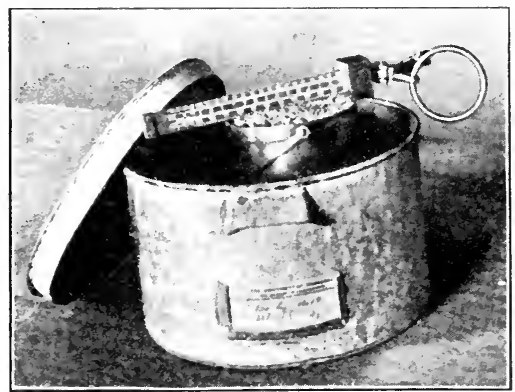

Fig. 24. A half-bushel galvanized iron box used in storing grain samples; also used in the general practice work of judging and srading grains

The difference in opinion seems to be due largely to the difference in methods of hrewing, and the special qualities sought for in the two comtries. For example, in America large quantities of corn or rice are used with the barley in brewing, which necessitates the use of a barley of much higher diastatic power than is required in Europe where the barley alone is used. 


\section{Jominga MarLer \\ score Card for Barley}

Variety Name

Number of Exhibit

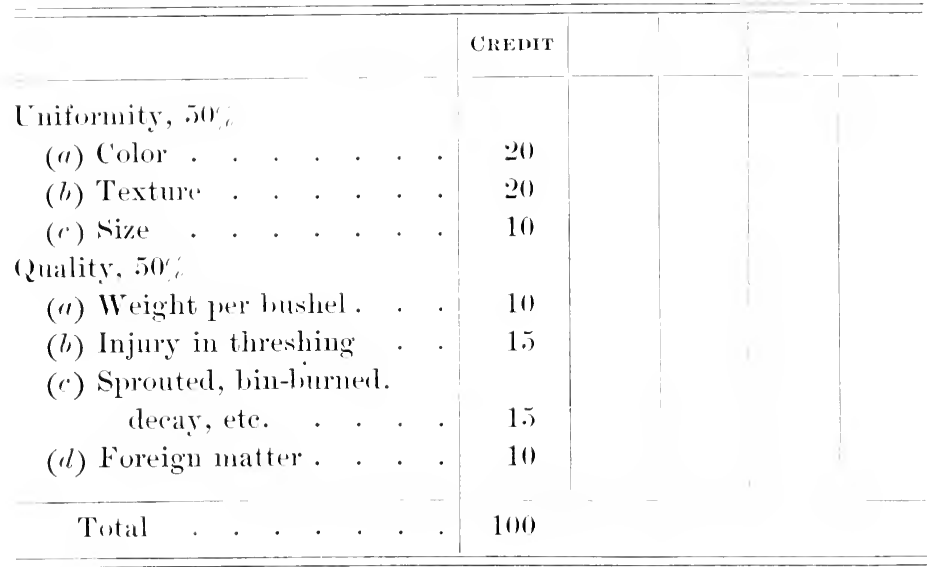

Student's Ninne

late.

\section{Explenation of seore cherd}

Barley is judged entirely from the brewer's standpoint, since it is the hrewing qualities of a barley that determine its market value. Brewing harley sells 10 to 20 per cent higher than feeding barley. In judging barley the following characteristics are taken into consideration.

Uniformity. Whatever the character or the variety of a barley may be, it is very important that it be uniform in quality. For example, in germination it is essential that all the grains germinate at one and the same time; but if part of the barley germinates in thirty hours, part in forty hours, 
and part in sixty hours, it is not as valuable for malting purposes as a barley which germinates uniformly at some one period. Where a barley has been exposed to the weather until considerably damaged, part of the grains may be sprouted, part more or less affected, and another part uninjured. Such a barley cannot germinate evenly. Though it may have been a first-class barley of heary weight to begin with, it is not as valuable for malting purposes. as a lighter barley of uniform sprouting qualities. For similar reasons barley should be uniform in color, variety, size of grain, age, storage conditions, etc.

Cniform ity in Color. Separate a sample into two or three parts accorting to color, i.e. different degrees of discoloring. Let the class having the highest number determine the color of the sample, and cut one point for each one per cent in other classes.

Uniformity in Terture. Barleys have hoth horny and starchy textures, the same as wheats. For brewing purposes they should all be uniformly one or the other. Divide the sample into two parts according to texture and hardness of berries. Let the part having the highest number determine the classification of the sample, and cut one point for each one per cent of other kind.

Uniformity in Size. Divide the sample into two parts, according to size of grain. Let the part having the largest volume or weight determine the classification, and cut one point for each two per cent of other sizes.

Weight per Bushel. Good malting barley should weigh from 40 to 50 pounds per bushel. While a heary-weight barley usually has a less per cent of hull and a higher per cent of starch, yet other considerations are of so much 
importance that a forty-pound harley may easily outsell a much heavier one. Barleys are largely sold by sample. Howerer, other things being equal, a heavy barley is preferred.

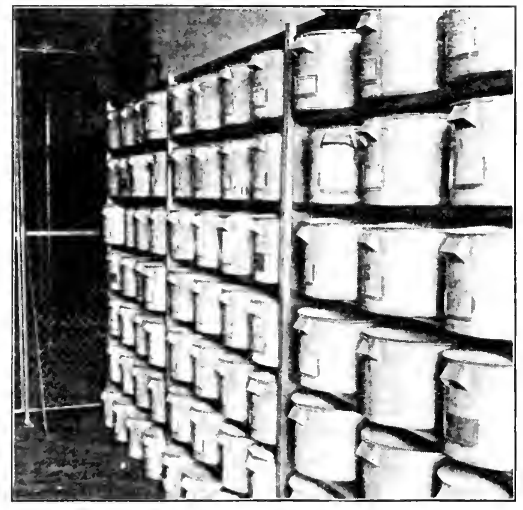

Fitr. 25. A view of the laboratory storeroom

Cut one point for each pound below 45 pounds per bushel.

Injury in Threshing. If harley is threshed too "close," many of the awns will be loroken so short that the tip of the berry will be exposed or the hull will be split down the back. Grains so injured alssorb water rapidly and do not malt uniformly with uninjured grains. Cut one point for each per cent so injured. Sprouted, Bin-Burned, or Decayed Groins. Estimate by counting and cut one point for each one per cent off.

Foreign Mroter. Estimate per cent by weight and cut one proint for each one per cent.

\section{Commercha Grantrof of Barley}

The work in commercial grading is carried out ly first examining a set of standarl samples representing the commercial grades; then as large a set of miscellaneous samples as possible should be examined and graded according to official inspection rules. The samples previously examined in sturlying harley should be graded, as the student alrearly has a good knowledge of these. 


\section{Barley Inspection Rules ${ }^{1}$}

No. 1 barley shall be sound, plump, bright, clean, and free from all other grain.

No. 2 Barley shall he of healthy color, not sound enough and plump enough for No. 1, reasonably clean, and reasonably free from other grain.

No. 3 Barley shall include slightly shrunken and otherwise slightly damaged barley not good enough for No. 2.

No. 4 Barley shall include all barley fit for malting purfoses not grool enough for No. 3.

No. 5 Barley shall include all barley which is harly damaged or for any reason is unfit for malting purposes, except that barley which has been chenically treated shall not be grated at all.

Blurli Burley. The grarles Nos. 1, 2, 3, and \& Black Barley shall conform in all respects to grarles Nus. 1, 2, 3, and 4 Barley, except they shall be of the black varieties of barley.

In examining and grading barleys the brewing and feeding qualities should be kept in mind. Note with care the color, texture, and brewing and feeding qualities of each sample. Report on these points with the grade of the sample, after the following manner:

\begin{tabular}{|c|c|c|}
\hline $\begin{array}{c}\text { NUMBER OF } \\
\text { SIMPLE }\end{array}$ & GRAIE & IREMARKS \\
\hline$\ddot{2}$ & Xn.:3 liarley & $\begin{array}{l}\text { Plump lut yuite bleached; good feeding } \\
\text { value. }\end{array}$ \\
\hline
\end{tabular}

1 Rules adopted by the Board of Railroad and Warehouse Commissioner's for the inspection of grain at Chicago. 


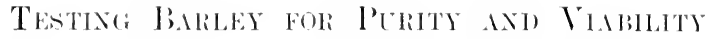

In testing barley for purity and germination follow the directions given for oats.

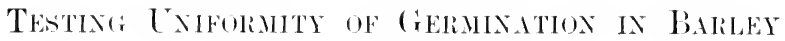

All seed grains, as barley, wheat, or oats, should germinate strongly and uniformly. Take three or four different samples of harley, such as a good bright one, one that has suffered more or less from exposure, and one bally damaged by field exposure; also mixed lots, as a mixture of two-rowed harley, brewing barley from the Pacific coast, and a Wisconsin sixrowed barley. A grain is considered germinated when the radicle is one fourth inch long. Carefully germinate 100 or more grains of each sample, and report as follows:

\section{lirport on cremination of Burleys}

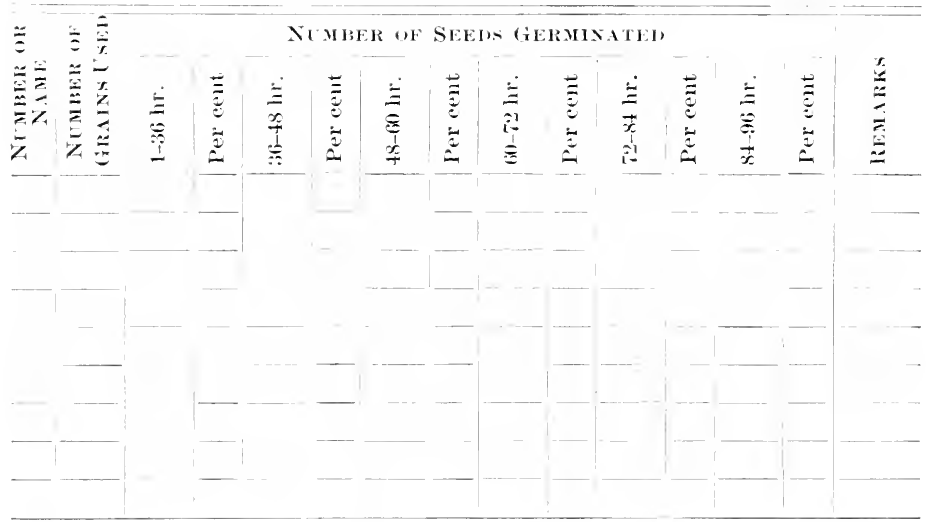

I raw curves on coördinate paper showing the rate and uniformity of germination for each sample. 


\section{SECTION V-HAY PLANTS}

\section{LABORATORY STLDY OF CHARACTERS}

The following outline is used in the sturly of common cultivated grasses and millets. By following the outline one's attention is called to the distinguishing characteristics of each kind, giving not only a means of identification but a good knowledge of the grass.

\section{()TTLINE FOR DESCRIBNA: (ARASSES}

The stem and leares

Ileight

Color of stem

Color of leaves

Number of leaves

IItrat

Awned or awnlesis

Paniclerl, compact, or spiked

size (give length and dianeter)

C'olor of awns

C'olor of chaff

\section{lioot}

Does it sprear from rootstocks?

Is it a sod-forming or hunch grass?

sreets:

size (give average length in inches)

Color (general color)

General Notes

Is seed free or incloserl in seales"?

Weight per lushel

Amount sown per acre.

Vitality

Mrouings of Seeds. Make drawing from convex side. Make drawing of cross section. 


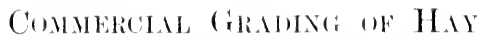 \\ Hon and Stroun Inspection Rentes 1}

Choice Timothy Hay shall be Timothy not mixed with orer one twentieth other grasses, properly cured, bright natural color, somml, and well halem.

No. 1 Timothy Hay shall be Timothy not more than one fifth mixerl with other tame grasses, properly cured, goord color, sound, and well baled.

No. 2. Timothy Hay shall include Timothy not good enough for No. 1, not over one third mixed with other tame grasses, sound, and well haled.

No. 3 Timothy Hay shall inclute all hay not goon emough for other grades, somnd, and well baled.

No. 1 Clover Mixed Hay shall be Timothy and Clover mixed, with at least one half Timothy, good color, somd, and well baled.

No. 2 Clover Mixed Hay shall be Timothy and Clover mixed, with at least one third Timothy, reasonably sound, and well baled.

No. 1 Clover Hay shall be medium Clover, not over one twentieth other grasses, properly cured, somml, and well baled.

No. 2 Clover Hay shall be Clover, sound, well haled, not good enough for No. 1.

No cracle Hay shall inclute all hay bally cured, musty, stained, threshed, or in any way unsound.

Choice Prairie Hay shall be Ipland Hay of loright color, well cured, sweet, sound, and reasonably free from weeds.

1 Rules arlopted by the Chicago board of 'Trade for the inspection of hay and straw. 
No. 1 P'rairie Hay shall be Lpland, and may entain one quarter Midland of good color, well cured, sweet, somnl, and reasonably free from weeds.

No. 2 Prairie Hay shall be Upland of fair color, or Midland of good color, well cured, sweet, somnd, and reasonably free from weeds.

No. 3 P'rairie Hay shall be Midland of fair color, or slough of good color, well cured, sound, and reasonably free from weeds.

No. 4 Prairie Hay shall include all hay not good enough for other grades, and not caked.

No Grade Prairie Hay shall include all hay not good enough for other grades.

No. 1 Straight liye Straw shall be in large hales, clean, bright, long Rye Straw, pressed in humlles, somnd, and well balerl.

No. 2 straight live Straw shall be in large bales, long live Straw, pressed in bundles, somnd and well baled, not good enough for No. 1.

Tangled Rye Straw shall be reasonably clean Rye Straw, good color, sound, and well baled.

Wheat Straw shall be reasonahly clean Wheat Straw, sound, and well baled.

Oat Straw shall be reasomably clean Oat Straw, sound, and well baled.

Eremining Hay or Strow. With a sharp hay knife cut the bale or pile of hay or straw in two. Then cut off a section about five inches thick. Carefully save the section removed, and seprarate into its various parts, as Timothy, Cluver, weeds, etc. Determine the amount of each by weight. 


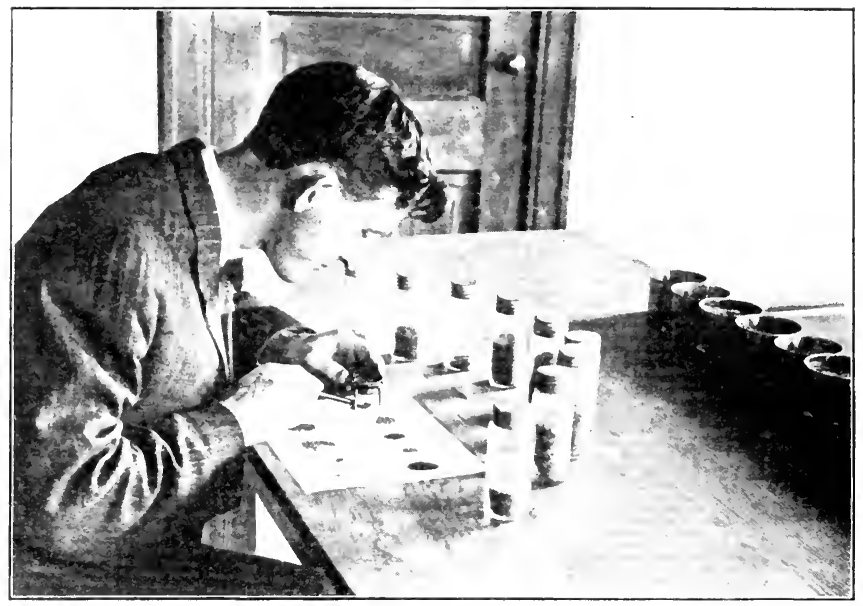

Fir. 26. A stment irlentifying clover seed

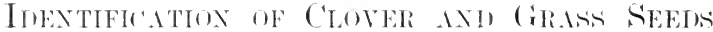

There is no work which requires nore careful attention or is more valuable than the identitication of grass and clover

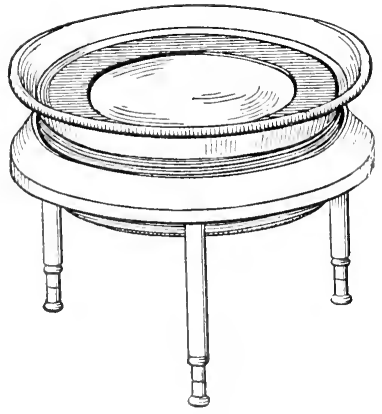

Fri, 27. Tripon lens used in identifying seeds. seeds, and separating them from their arlulterants.

For examining the seeds a small tripod lens is very useful. Use the following artiticial key, which is not intended to describe the seed but simply calls attention to the most prominent characteristics of each variety. It is much better to first learn to identify by use of the key than by use of the drawings. 


\section{Key for Ielentifiertion of CHorer steds}

seed free (not inclosed in pod)

seed bean-shaped

Color, pinkish, ${ }_{s}^{1}$ in. long.

Crimson Clover

Color, mostly yellow; large seeds are kidney shaperl. Alfalta

(Trukestan alfalfa is same, but slate colored.)

Seeds larger and more regular than in alfalfa Burr C'lover

color, dark yellow to brown Yellow Trefoil

seed oval-ololong

('olor, yellow; seed notched near one end ..... Bokhara Clover seed heart-shaped

color, yellow to brown White Clover

Color, dark green to black Alsike Clover

seed somewhat triangular

Color, yollow to brownish

Red clower

siened inclosed in perd

Perl latrese and cormeruated, $\frac{1}{4}$ in. long

Color, brown; sered, lecall-shaped

sainfoin

Poul whitish, ${ }_{x}^{1}$ in. lomg

color, yellow ; sered oval, motebed near end

Yellow sweet Clover

Pod brown, ${ }_{s}^{1} \mathrm{in}$. Jong

Color, dark brown, seed mottled Japan Clover

\section{Key for Intentification of Grass Seed.}

seeds distinctly awned

Seed $\frac{1}{4}$ in. or more in length

Very hairy or pubescent, flat, thin Meadow Foxtail

Awns attached at tip, Anmual liye Grass

Awns long, twisted, attached near lase

Tall Meadow Oat (irass

seeds less than $\frac{1}{4}$ in. long

sinall brownish seed sheep, Fescme 


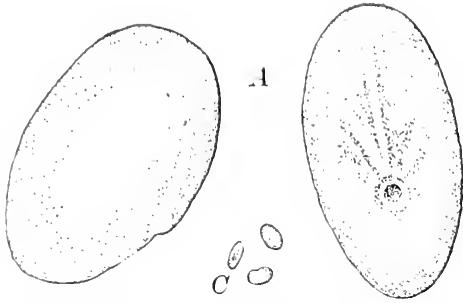

Fı, 28. ('rimson dover: $A$, magnified seeds ; $C$, natmal size
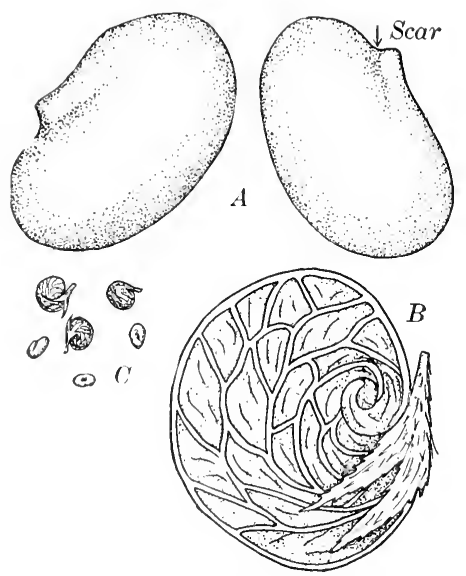

Fir. 30. Yellow trefoil: A, magnified seeds; $B$, magnified seed pod; C. natural size
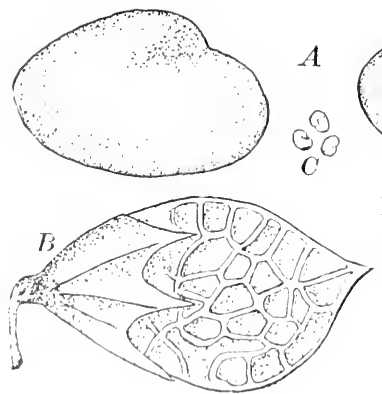

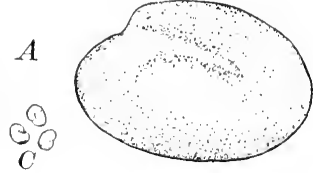

Fin. 32. Bokhata (lover : $A$, magnifierl seerls ; $B$, magnified seed porl, C, natmal size

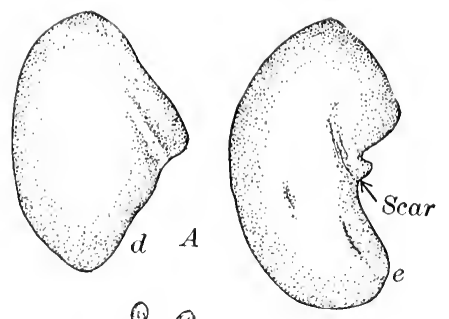

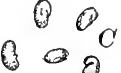

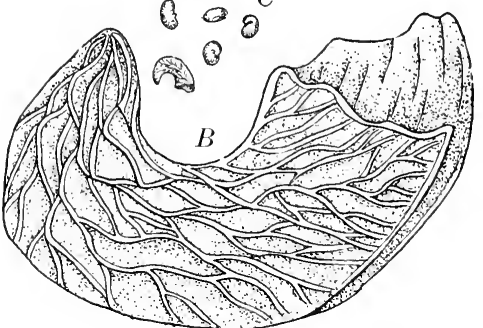

Fin. 2!. Alfalfa: $A$, magnified seeds, (d) short type, (e) long, curver type; $B$, magnified seed pod ; $C$, natmal size

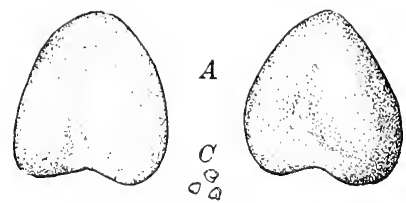

FIG. 31. White clover: 1 , wagnified seerls; $C$, natmal size
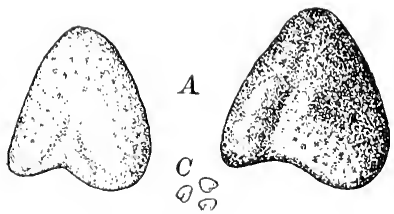

Fir. 33. Alsike clover: $A$, magnified seerls; $C$, natural size 


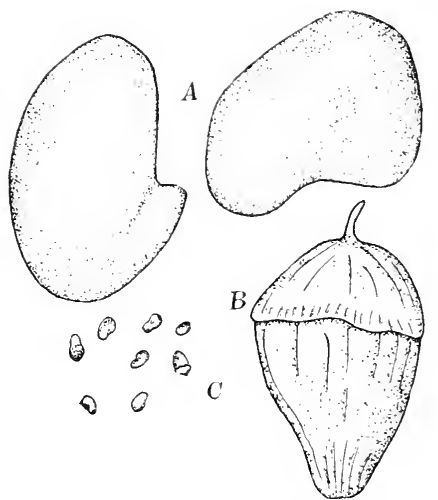

Fic, 34. Red clover: $A$, magnitied seeds; $B$, magnitied seed porl; $C$, natural size

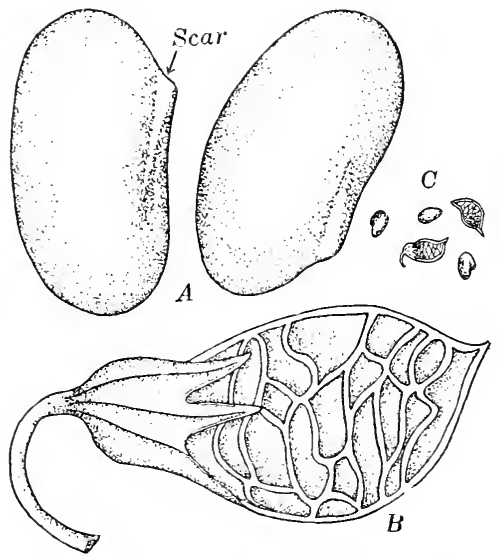

Fic, 36. Sweet clover: $A$, magnified seeds; $B$, magnified seed pod ; $C$, natural size

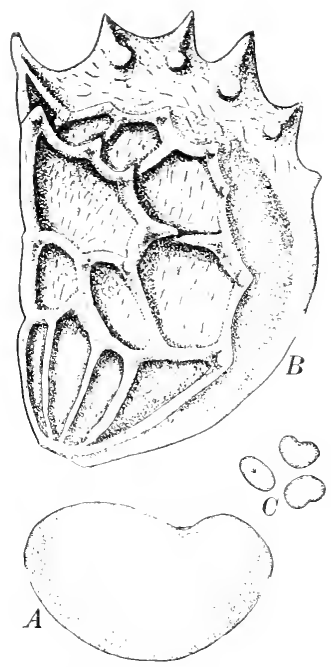

For. 35. Sainfoin: $A$, magnifier seerl; $B$, matnified seed perd; (', natural size
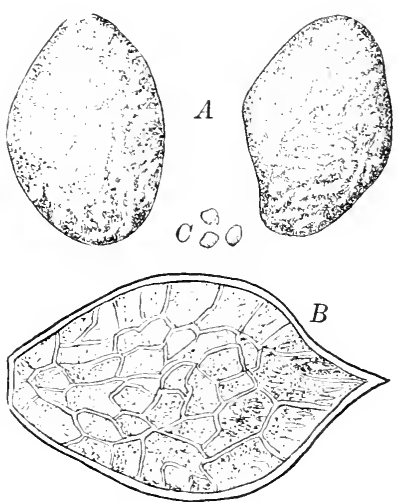

Fra. 87. Japan clover: $A$, magnified seeds; $B$, magnified seed por : C. natural size 
Short-at meed or a a wh-prointed

small, dark brown serefls, very romgly near tip

3 in. lome. smooth. light coloreel

C'rested Dog's-Tail

lin. or less in length

Wheat Grass

Orehard Grass

Awnless

: in. long or therealunt, nerves very pominent Brome Grass

Alont $\frac{1}{4} \mathrm{ind}$. lomg Sote difference in shape Peremial lige Cirass light hrown ... and size of rachillat $\}$.... Mtealew Fescue Hard, smoeth seeds, alont $\frac{1}{4} \mathrm{ins}$ long

I) ark hrown color Johuson Grass ? in. lomg or less

Kenel romgly, sawlike Riedtop'

lieel not commonly rollgh Kentueky Blue (irass seed free from glumes. polisherl

Very small, $\frac{1}{3}$ in. in length. polished

Timothy

\section{Ke'y for Intentificetion of Millet seded.}

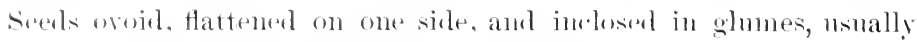
shing. frem $\frac{1}{10}$ to $\frac{1}{20}$ in. in lengtl

resed red ol pink - iherian Millet seed yellow (ierman Millet

Seet mostly black IImgarian Grass seed dull brown, outer corering loose and romgle

Japranese Barnyard Millet seed brownish yellow (rarieties of this millet are white and other's red)

Broomeorn Millet
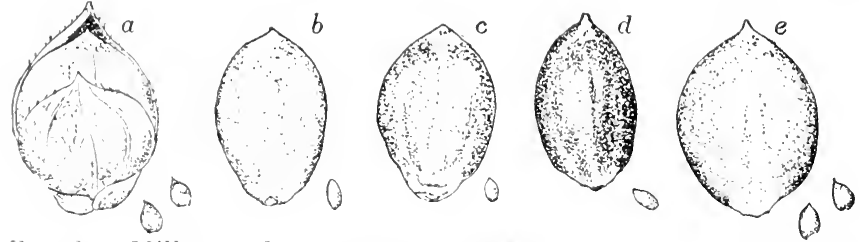

Frr. 3r. Millet seeds: (a) Japanese Millet (Panienm crus-galli) ; (7) (ierman millet (Chetoehloa italiea); (c) Siberian millet (Cheetochloa italica): (d) Hungarian millet (Chetochloa italica);

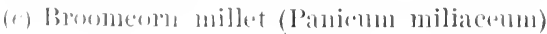




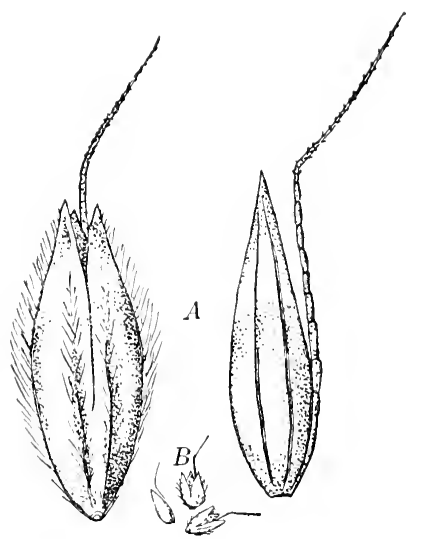

Frti, 89. Neadow foxtail : $A$, magnified seeds; $B$, natural size

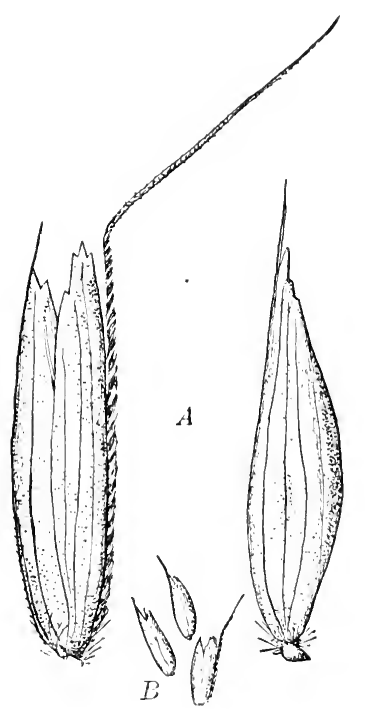

Fig. 41. Tall meadow oat grass: $A$, magnified seeds ; $B$, natural size

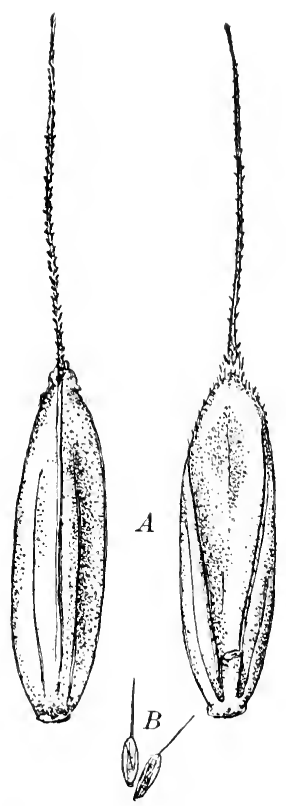

Fic. 40. Amnual rye grass: $A$, magnified seeds; $B$, natural size

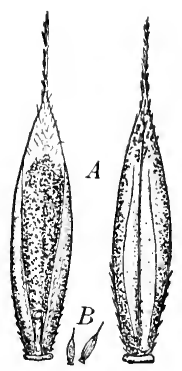

Fic. 42. Sheep fescue: $A$, magnified seeds; $B$, natural size 


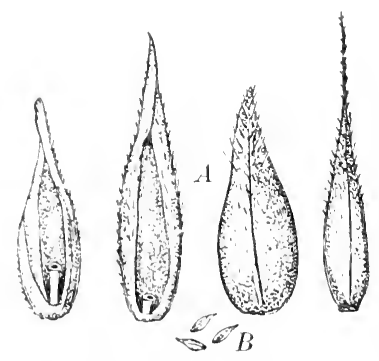

Fri. 4:). ('resterl dogr's-tail: A, mannified sereds; I', natural size

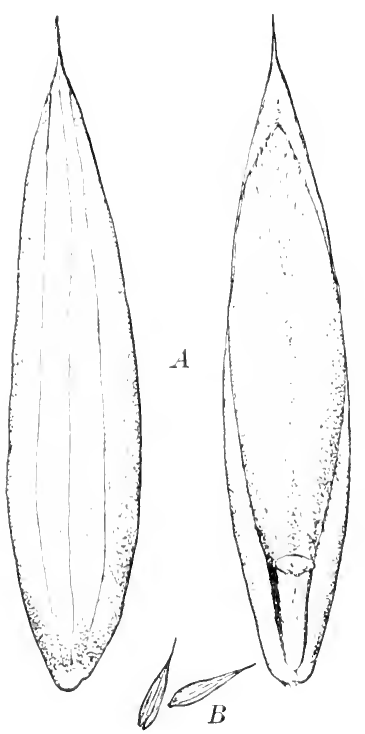

FIr, 44. Wheat grass: 1, magnified seerls; $B$, natmal size

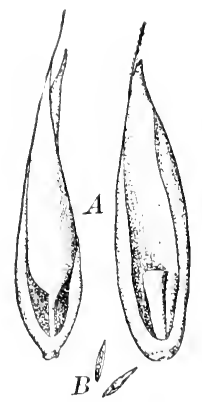

Fro. 45. orehare grass: 1 , magnified steds ; I3, natmal size

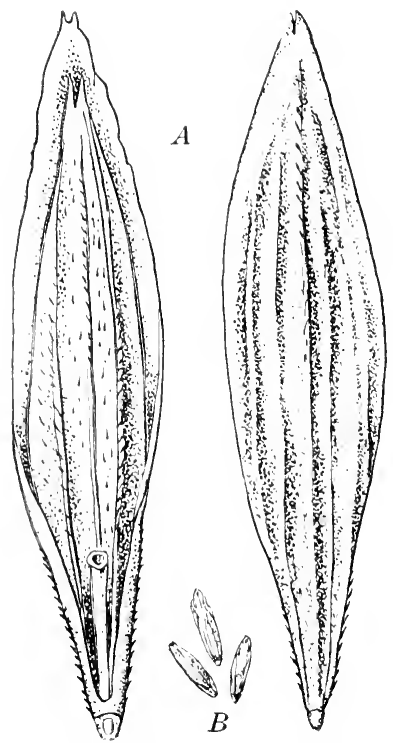

Fic. 46. Brome grass: A, magnitied secerls; 1 , natural size 


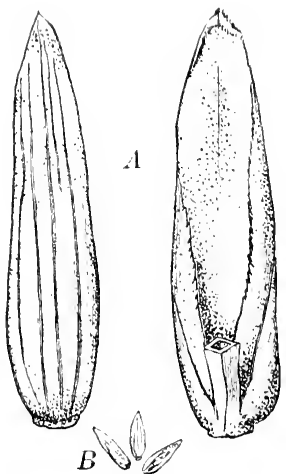

Fu, 47. P'erennial rye grass: 1, magnified seeds ; $B$, natniral size

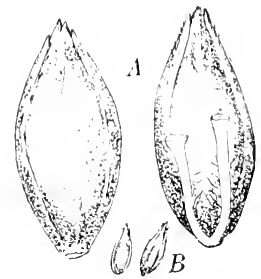

Fic. 4!). Johnston graks: 1 , mannitiel sexers ; $B$, natural size

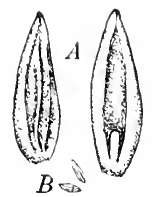

Fir, 51. Kentucky blue grass: A. magnified seeds ; $B$, natural size

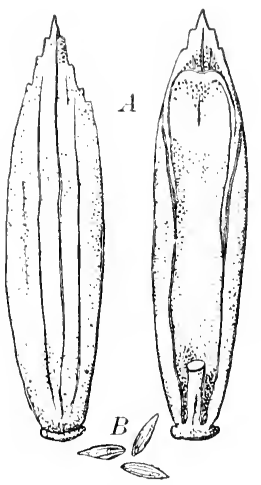

Fin. th. Mearlow fesente: 1 , manguified seeds; $B$, natural size

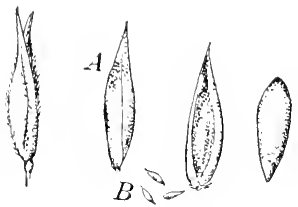

Fir. 50. Redtort: A, magnified seeds; $B$, natural size

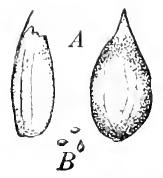

Fir, 52. Timothy: 1 , masnified seeds; $b$, natural size 


\section{SEEI TESTING}

\section{APPARATLS FOR GERMINATING SEEIS}

Germination tests are easily made, even with the simplest a) paratus.

A seed incubator is generally made on the plan of an oven, double walled, and often covered with asbestos. The space hetween the douhle walls may be filled with water. This is usually heated with a gas jet or lamp so arranged that a fairly constant temperature can be maintained.

The seerls are placed in trays, between or upon moist blotting fapers, and kept in the incubator, which is closed up in order to produce a moist atmosphere until germination is complete. The best temperature for germinating most cereal seeds is hetween $80^{\circ}$ and $90^{\circ} \mathrm{F}$., but grass seeds should not he heated above $70^{\circ}$, and the temperature should daily be reduced to $50^{\circ}$.

\section{HOMEMALE ( EERMINATORS}

One of the simplest and most practical germinators can he makle hy taking two common dimner plates and placing in the bottom of one of them two or three layers of filter paper or other ahsorbent and thoroughly wetting it. Place the seerls to be tested on top of this. If the seeds are large, as corn or wheat, you may cover them with blotting paper or a cloth, thomgh this is not necessary. Small seeds, such as (forer or glass, do better if not covered. 
Now invert the second plate over the first, being careful to have the elges fouch evenly. This makes a moist chamber, and gives the most favoralle conditions for germination.

Similar moist chambers may be tixed up by using any shallow bucket or pan having a cover, or tin or wooden

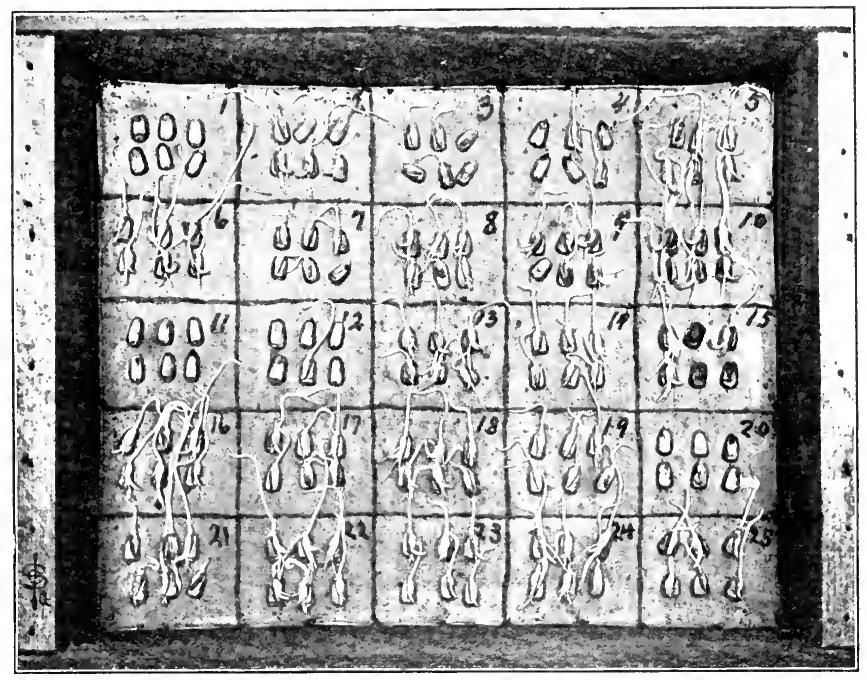

FIt. 53. A corn germinator. The six grains in each stuare are taken from a different ear. (Iowa Bulletin No. ${ }^{2}$ )

boxes may be userl, such as toluace and cigar boxes, all of which when userl properly will give satisfactory results.

The accompanying photograph (Fig. 5:3) illustrates a very handy device for testing individual ears of seed corn. It is made about two inches deep, and any convenient size. Place in the bottom some absorlient material to hold the moisture, - an inch of sawlust or sand, or a few layers of cloth or 
hlotting paper. Whatever is used, the top should be covered with a piece of white blotting paper or cloth. Mark this off into two-inch squares or larger, or cover with a piece of wire netting. After the corn grains are placed on the cloth they should be covered with cloth, or the box covered with a close-fitting cover.

\section{A STLPY OF TIIE GERMINATION OF SEEDS}

(Prepared by A. T. Wiancko, Purdue University)

Tse seeds and hoxes provided. Place a piece of blotting paper in the bettom of each box and have a second piece to cover the seerls. Saturate both pieces of blotting paper. Comt 25 kernels each of corn and wheat and place in one of the boxes. Count out the same number each of clover and leans, and place in the second box. Cover these seeds with the second piece of blotting paper. P'ut on the lid and set aside. Examine every day to note progress of germination and condition of moisture.

1. What is the first act in the process of germination?

2. Which appears first, the radicle (root) or the plumule (leaves)?

3. How many days are required for germination!

4. Is there any difference in the manner in which the cotyledon (seed) is disposed after germination? Explain.

万. Two modes of root development: axiul, the radicle extenrling into a taproot with more or less branches; diffuse, no evidence of taproot, but numerous long, slender roots. Which of these seeds show such development? Does this teach anything with regard to soil preparation?

6. Look for the rootcap. What seems to he its office? 
7. Olserve the root hairs. What do you conclude their function to be? Do they teach anything about soil preparation?

8. Make drawings illustrating different stages of develop'ment and showing the various points mentioned above.

9. If possible try the germination under cooler temperature and note results.

\section{DETERMINING THE PIRE ANI (ERTINABLE SEEDS}

\section{IN $A$ SAMPLE OF ('LOTER SEEI)}

(Prepared by A. T. Wiancko, Purdue University)

The metal capsule furnished has one gram of seed in it. Separate this sample into four parts: (1) pure seed that from appearance you judge would grow; $(\stackrel{2}{-})$ pure seer that from appearance you julge would not grow; (3) weed seeds; (4) sticks, thaff, dirt, ete.

Count the seeds in each division. Find what per cent each is of the total number. A pound contains 454.5 grams. Calculate the number of each kind of seeds in a bushel.

P'ut the seeds in each of the alove divisions into a moist chamber and give them the germination test. Calculate the per cent of each division that germinates. How does it compare with the mechanical separation? Calculate what per cent the seeds germinating in elasses (1) and (2) are of the total number of seeds. If this seed sells in the market for $\$ 8.00$ per bushel, what is the actual price per bushel for pure and germinable seed ?

A written report is requested one week from the close of the experiment. 
Siguesten Folid for likport

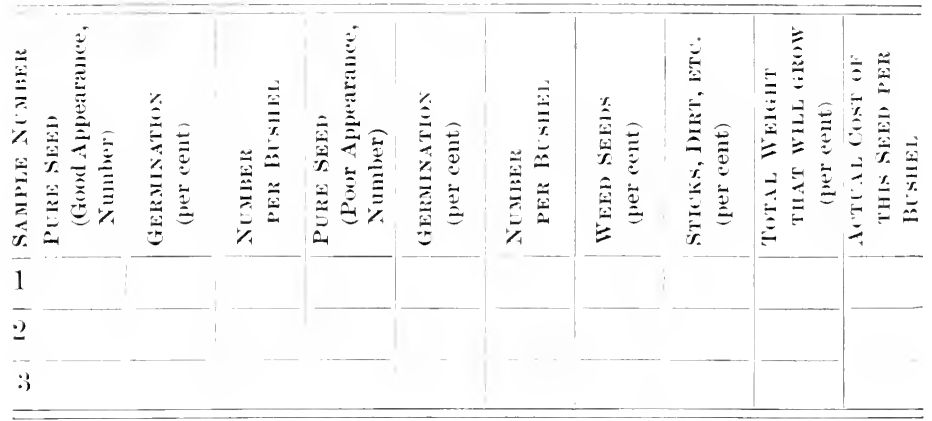

Name

liate

\section{DETERMINATION OF WEIGIIT PER BLSHEL}

Grain testers are usually made in three sizes - pint, quart, and two-ruart. When the measure is properly filled with grain and hung on the balance, the number of pounds the grain will weigh per bushel can be directly rearl.

The greatest care must be exereised in filling the measure. The arain should not be shaken or pressed down, hut should be allowed to fall as lonsely as possible into the tester. Io not dip the grain 11]' with the measure, hut take the measure in both hamds and foree it hottom down until the tol' is level with the grain: then seoop the grain in with the hands, allowing it to fall as loosely as possible. Then, being careful not to press or shake down the grain, stroke the tol) with a straightedge and hang on the halance.

A little practice will enable one to do fairly accurate work with the tester. 


\section{Practer Work WTTh Testek}

Try taking duplicate samples until you can get the same results every time.

Fill the sampler in various ways, such as dipping it into the grain, or shaking and pressing the grain down a little after the tester is filled, and compare weights with those obtained when tester is properly tilled.

\section{TEST FOR MOISTLRE IN GRAIN}

Use samples of corn of various grades, kept under different conditions, such as corn too wet to graule, corn kept in open crib since husking, eorn kepit in dhy seed room, ete. Also use samples of oats, wheat, and harley.

Sicmpling. After mixing up your sample carefully, take about two ounces and grind in a tine coffee mill, running it throngh several times, reducing as fine as possible. Then take a 1-gram sample and dry in a water oren to constant weight. The per cent of moisture is found by dividing by weight of original sample the difference between weight of miginal sample and dry sample. 


\section{LEGAL WEIGITS PER BLSIIEL OF SEEDS 1}

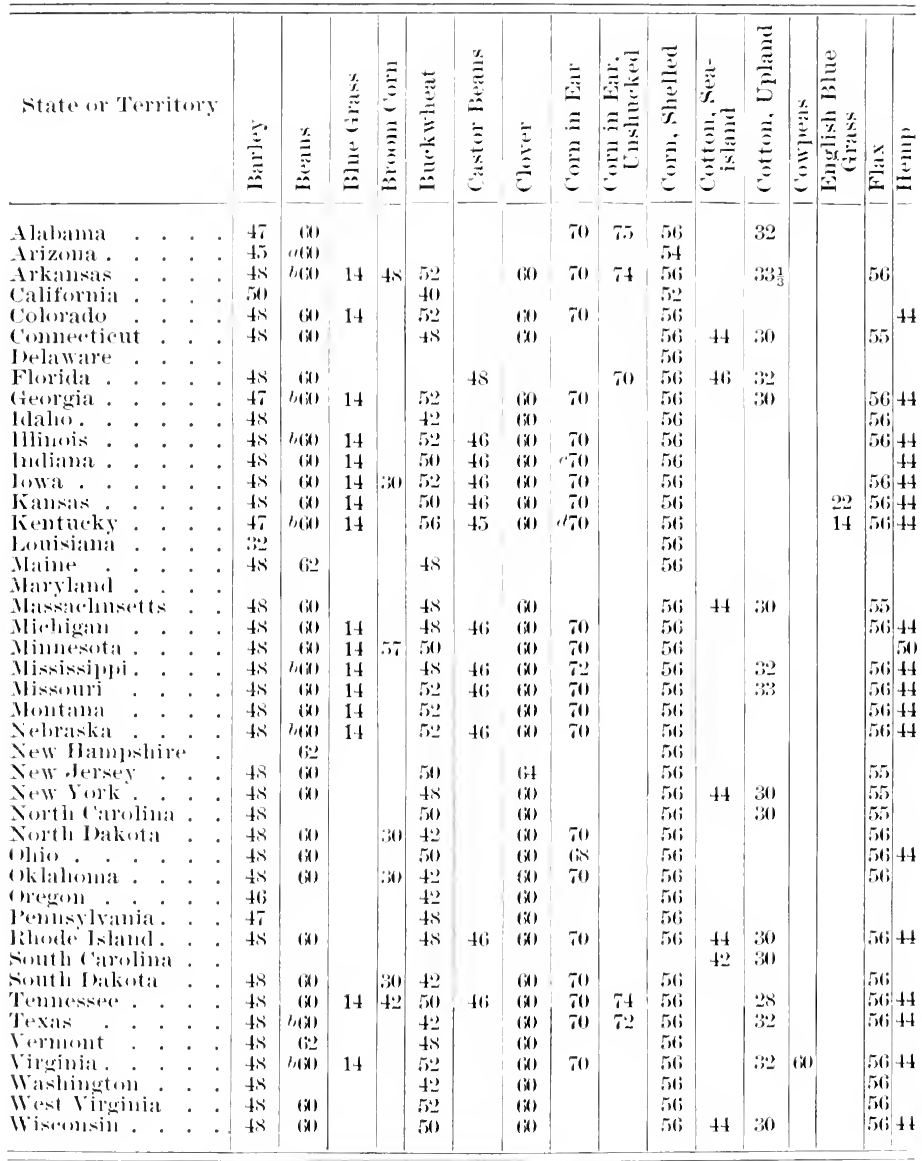

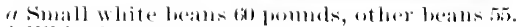

l, White healis.

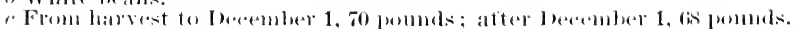

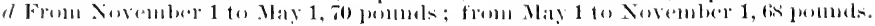

I Experiment station Work. Vul. II, No. 15. Compiled from Bulletin 51, Conited sitates Department of $\Lambda$ grienlture, Burean of Plant Imblustry. 


\section{LEGAL WEIGIITS PER BLSIIEL OF SEEDS (Comtimued)}

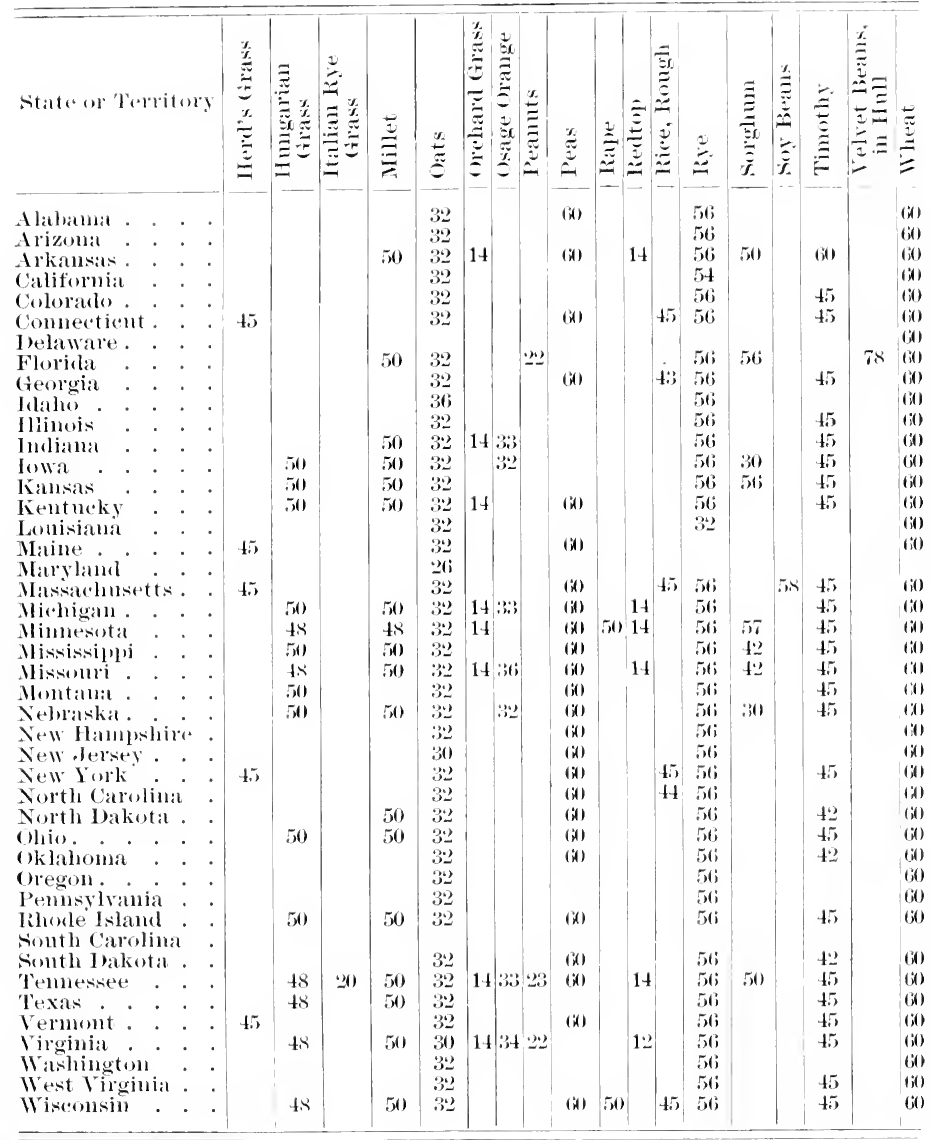

Weights of misceltomeons seeds mot imeluded in the tuble: Amber ane, New Jersey, 57 pommls per bushel; besgar weed. Florida, fiz pumbls; ramary seed, Temnessee, (a) pomnds; hickory mis, Temmessoe, of pommls; Indian wheat, Ver-

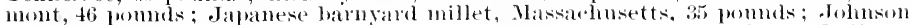
grass, Arkansas, 28 pounds; Katir coln, Kansas, 56 pounds; pop eorn in ear, Imbiama,

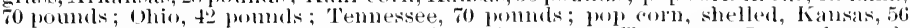
pomds; spelt, North Inakota, 48 pounds; velvet grass, Temnessee, 7 pommls; walints, 'Temmessee, 50 pommls. 



\section{TEXT-BOOKS ON SCIENCE}

FOR HIGHER SCHOOLS AND COLLEGES

Bergen and Davis's Principles of Botany . . . . . . \$1.50 \$1.65

Bergen's Elements of Botany. (Revised Edition) . . . $1.30 \quad$ I. 45

Bergen's Foundations of Botany . . . . . . . . . $1.50 \quad 1.70$

Blaisdell's life and Health . . . . . . . . . . . . 90 i.co

Blaisdell's P'ractical Physiology . . . . . . . . . I.IO 1.20

$\begin{array}{llll}\text { Brown's Physiology for the Laboratory. . . . . . . . } & .75 & .85\end{array}$

Byrd's Laboratory Manual in Astronomy . . . . . . . $\begin{array}{rrr}1.25 & 1.35\end{array}$

Davis's Elementary Meteorology . . . . . . . . . $2.50 \quad 2.70$

Davis's Elementary Physical Geography . . . . . . $\begin{array}{lll}1.25 & 1.40\end{array}$

Davis's Physical Geography . . . . . . . . . . . I.25 1.40

Gage's Elements of Physics. (Revised Edition). . . . I.I2 I.20

Hastings and Beach's General Physics . . . . . . . 2.752 .95

Higgins's Lessons in Physics . . . . . . . . . . $\quad .90 \quad 1.00$

Hough and Sedgwick's Human Mechanism . . . . . 2.502 .65

Linville and Kelly's Zoölogy $\quad . \quad$. . . . . . . . . . $1.50 \quad$ 1.70

Meier's Herbarium and Plant Iescription. With directions for collecting, pressing, and mounting specimens

McPherson and Henderson's Elementary Study of Chemistry

Millikan and Gale's First Course in Physics . . . . .

Noore's Laboratory Directions for Beginners in Bacteriology . . . . . . . . . . . . . . .

Nichols, Smith, and Turton's Manual of Experimental Physics

Norton's Elements of Geology

Pratt's Invertebrate Zoölogy.

Sabine's Laboratory Course in Physical Measurements.

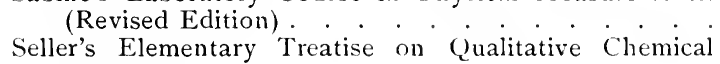
Analysis . . . . . . . . . . . . . . . . $\quad .75 \quad .80$

Stone's Experimental Physics . . . . . . . . . . I.00 I.10

Ward's Practical Exercises in Elementary Meteorology . I.I2 1.25

Wentworth and Hill's Text-Book of Physics . . . . 1.15 1.25

Wentworth and Hill's Laboratory Exercises in Elementary Physics. (Revised Edition) . . . . . . . $\quad \begin{array}{lll}.25 & .30\end{array}$

Williams's Elements of Chemistry . . . . . . . . I.10 1.20

Young's Elements of Astronomy . . . . . . . . . $1.60 \quad 1.75$

Young's General Astronomy . . . . . . . . . . $\begin{array}{lll} & 2.75 & 3.00\end{array}$

Young's Lessons in Astronomy. (Revised Edition) . . $\begin{array}{lll}\text { I.25 } & 1.40\end{array}$

Young's Manual of Astronomy . . . . . . . . . $\begin{array}{llll}2.25 & 2.45\end{array}$ 


\section{TIPES AND BREEDS OF FARM ANIMALS}

By CHARLES SUMNER PLUMB, Professor of Animal Husbandry in the College of Agriculture of the Ohio State University

8 vo. Cloth. 563 pages. Illustrated. List price, $\$ 2.00$; mailing price, $\$ 2.20$

TYPES AND BREEDS OF FARM ANIMALS

1 supplies the need for an up-to-date discussion of the several types and breeds of horses, asses, mules, cattle, sheep, goats, and swine. This volume describes the commonly accepted types, as, for example, draft or speed type of horse, dairy type of cattle, and bacon type of swine. It includes discussions of the original habitat, breed development, European history, special American history, work of pioneer breeders, famous animals, families, or tribes, breed characteristics, breed and individual records (as, for example, milk of cows, butter, or speed of horses, etc.). Many noteworthy records are given and numerous illustrations of famous animals shown. A comprehensive table of contents and an index form an important part of the book.

The work is primarily intended for students in agricultural colleges and universities. Breeders and feeders of animals, however, will find this volume a valuable reference work.

\section{GINN \& COMPANY Publishers}




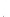
. 


\section{,}


North Carolina State University Libraries

SB189.L97

EXAMINING AND GRADING GRAINS

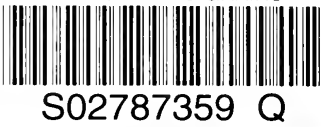

